\title{
Transition to farming - transition to milk culture: a case study from Mala Triglavca, Slovenia
}

\author{
Mihael Budja ${ }^{1}$, Nives Ogrinc ${ }^{2}$, Andreja Žibrat Gašparič ${ }^{1}$, Doris Potočnik ${ }^{2}$, Dušan Žigon ${ }^{2}$ \\ and Dimitrij Mlekuž ${ }^{1}$ \\ 1 Department of Archaeology, Faculty of Arts, University of Ljubljana, SI \\ miha.budja@ff.uni-lj.si \\ 2 Department of Environmental Sciences, Jožef Stefan Institute, Ljubljana, SI \\ nives.ogrinc@ijs.si
}

\begin{abstract}
In this paper, we discuss the transition to milk culture. While archaeological and biochemical data suggest that dairying was adopted in the Neolithic in Europe, archaeogenetic data show the absence of the allelic variant $-13910 * T$ and very low lactase persistence in Neolithic populations in Europe. The Mala Triglavca case study shows that the Early Neolithic economy in the Caput Adriae region was mixed. It consisted of milk and processed milk, meat animal products, freshwater fish and various plants. The Vlaška group herders managed a broader spectrum of resources than exclusively ovicaprids, and were able to produce a wide range of low-lactose, storable products by fermenting milk.
\end{abstract}

IZVLEČEK - V članku razpravljamo o uporabi mleka in mlečni kulturi v prazgodovini. Medtem ko arheološki in biokemični podatki kažejo na razvoj mlekarstva v neolitiku v Evropi, arheogenetski govorijo o odsotnosti alela -13.910*T in laktozne persistence pri neolitskih populacijah v Evropi. Raziskave v Mali Triglavci kažejo, da je bilo gospodarstvo $v$ zgodnjem neolitiku na območju Caput Adriae mešano, t.j. mlečno in mesno. Temeljilo je na uporabi mleka in mlečnih izdelkov, mesa prežvekovalcev in neprežvekovalcev, sladkovodnih rib in različnih rastlin. Pastirji skupine Vlaška so v svoje gospodarstvo poleg vzreje drobnice vključili tudi druge vire. $S$ pomočjo fermentacije so predelovali mleko $v$ mlečne izdelke.

KEY WORDS - European Neolithic; demic diffusion; transition to farming; dairying; lactase persistence; lipids; Vlaška culture

\section{Introduction}

The beginning of dairy culture can be assumed to have occurred in the processes of the transition to farming, and the utilisation of lactic acid bacteria can be traced alongside the domestication of sheep, goat and cattle. In milking and milk processing, the lactococci and lactobacilli were manipulated to initiate the fermentation that converts milk into yogurt, buttermilk, butter and cheese. These have advantages in storing and transporting dairy products and making them available in times of low milk production on one hand, and making milk available as a nutritional source throughout the entire life of the individuals on the other.
Biomolecular analyses of the lipids present in food which become absorbed and trapped in the pores of clay vessels show that milk was being used extensively by the $7^{\text {th }}$ millennium $B C$ in south-eastern Anatolia and around the Sea of Marmara. A millennium later, it was processed at some Early Neolithic sites in Southeast and Central Europe (Craig et al. 2005; Evershed et al. 2008). Parallel archaeogenetic studies hypothesised that a single mutation $\left(-13910^{*} \mathrm{~T}\right)$ in the human genome which allow adults to consume fresh milk evolved within a group(s) of Neolithic pioneer stockbreeders among whom lactase persistence was rare, but who initially practised dairying in 
Southeast Europe in the middle of $8^{\text {th }}$ millennium $\mathrm{BP}$ and later migrated towards central and northern Europe to an area inhabited by foragers. They reached the northern Adriatic at $c .7400 \mathrm{BP}$ (Gerbault et al. 2009; 2011; Burger, Thomas 2011; Gerbault 2012). However, the absence of the lactase gene in Neolithic populations in Europe shows that their lactase persistence was very low and 'may have even been zero' (Leonardi et al. 2012.93). Animal biomarkers observed in pottery in the Northern Adriatic suggest that dairy products were processed and stored at $c .6400 \mathrm{BP}$, and were associated with a mixed subsistence strategy based on meat (ruminant and non-ruminant origin), milk, plant and aquatic animals.

\section{Dairying and lactase persistence}

All humans have the lactase gene, but only children produce lactase in sufficient amounts to break down lactose, the main sugar in milk. Fresh milk is a toxin to adults without lactase, and often causes symptoms such as abdominal pain, bloating, flatulence and diarrhoea. Lactase is an enzyme produced in the digestive system of mammalian infants, but is dramatically reduced after the weaning period. The ability to digest lactose found in fresh milk is called lactase persistence. However, the correlation between lactase persistence and fresh milk consumption is not yet fully understood.

The lactase persistence trait is found in approx. 35\% of adults in human populations in the world, but varies widely between and within continents. The frequencies of lactase-persistent individuals are generally high in Europe, Central Asia and India but almost zero in Southeast Asia (Itan et al. 2010; Gerbault et al. 2011). In Europe, lactase persistence is at its highest frequency in the North, with a decreasing cline from the central and western (62-86\%) to the southern and eastern regions (15-54\%) (Gerbault et al. 2011.864). On the Indian sub-continent the frequency of lactase persistence is higher in the North-West than elsewhere; further East, the lactase persistence frequency is generally low. In Africa and the Middle East, the distribution is patchy, with some pastoral nomadic tribes having high frequencies (92\%) of lactase persistence compared with neighbouring groups living in the same region (Tishkoff et al. 2007; Ingram et al. 2009; Gerbault et al. 2011).

In a broader context, three main groups are distinguished according to milk and milk product consumption dependence. The first group has never used dairy animals and has not integrated lactose in their diet after weaning (e.g., Aborigines, Eskimos and other American Indians). The second group consists of pastoralists who have never integrated much milk or milk products into their subsistence (e.g., many African populations, Chinese Han, Thai). The third group relates to populations that introduced the practice of drinking milk a long time ago and had a high amount of lactose in their diet (e.g., most Europeans, some African and Middle Eastern populations and North Indians). There are some exceptions, for example, populations that have low lactase persistence, but drink fresh milk (i.e. Mongols, Dinka and Nuer in Sudan and the Somali in Ethiopia) (Liebert 2012.83).

The global correlation between lactase persistence frequencies and patterns of historically milk drinking populations led to the broadly accepted notion that lactase persistence has been subject to positive selection. This has become known as 'gene - culture coevolution' or the 'culture historical hypothesis', suggesting that the rise in lactase persistence co-evolved alongside the cultural adaptation of milk consumption and its associated nutritional benefits.

A number of single nucleotide polymorphisms that allow lactase to be produced into adulthood have been found in different modern human populations worldwide. They are not located in the lactase gene (LCT), but in the intron of a neighbouring gene, MCM6, on chromosome 2. Several nucleotide changes in this region seem to affect lactase the gene promoter activity associated with lactase persistence (Gerbault et al. 2011.864). They have different geographic distributions within the modern populations. The derived allelic variant $-13910 * \mathrm{~T}$ of the first nucleotide cytosine to thymine transition C>T-13910 is associated with lactase persistence in Europe, Central Asia and India (Enattah et al. 2002; Ingram et al. 2007; Itan et al. 2009). This allele and associated selection for lactose tolerance seems to originate twice in ancestral populations (bearing haplotypes $\mathrm{H})$ in regions north of the Caucasus and West of the Urals. The first origin is estimated at 12000 to 5000 $\mathrm{BP}$, and the second more recently at 3000 to 1400 years ago. It was suggested that the frequency gradient in modern populations shows that the allele migrated to the West (Enattah 2007.619-622).

Lactase persistence in Africa is linked to three single nucleotide polymorphisms, C-14 010, G-13 915 and G-13 907, close to the lactase gene (Tishkoff et al. 2007). They are linked to different ethnic groups 
with divergent haplotype backgrounds and geographic regions. However, some questions still remain unanswered. The Hadza people in Tanzania show a high level of lactase persistence despite having nothing to do with herding. The possible explanation is that, although they are now mainly hunter-gatherers, their ancestors might have been pastoralists. European -13 910*T and East African G-13 $907 \mathrm{LP}$ alleles are very near to each other and probably share the same ancestral allele that "might have arisen because of a common domestication event of the cattle, whereas the C-3712 and G-13 915 allele in Arabia most likely arose due to the separate domestication event of camels" (Enattah et al. 2008. 70 ). The origin of the African allele $\mathrm{G} / \mathrm{C}-14010$ is estimated between $c$. 6800-2700 BP (Tishkoff et al. 2007.36).

Lactase persistence is one of the leading examples of natural selection in humans and also one of the first clear examples of the polymorphism of a regulatory in the human genome (Ingram et al. 2009). A single gene was involved with different mutations in different parts of the world, but with similar effects. The lactase persistence has been mainly identified in pastoralist populations and, as fresh milk and milk products are the only known naturally occurring sources of lactose, it is therefore unlikely that this trait would be selected without a supply of fresh milk (Gerbault et al. 2011.864). Why this trait was so strongly selected is still widely discussed.

Several scenarios relating to the 'selection hypotheses on lactase persistence' and to 'the advantage of being lactase persistent' have been discussed recently. The first and most widely accepted 'gene - culture coevolution' or 'culture historical' hypothesis proposes that lactase persistence was selected among populations that consumed milk over generations and adopted animal breeding and dairying, thereby increasing the dependence of adults on milk. In opposition, the second, the 'reverse cause hypothesis', suggests that dairying was adapted by populations that were already lactase persistent. A mutation associated with lactase persistence within small human groups could have grown in frequency through genetic drift before milk was introduced into subsistence. The third, the 'calcium assimilation hypothesis', suggests that in high-latitude environments where lower sunlight produces less vitamin D (important for the absorption of calcium in bones) lactose in fresh milk promotes the uptake of calcium present in milk. In contrast to hunter-gatherers who had a vitamin D rich diet abundant in marine food, early agriculturalist might have had problems with vitamin D deficiency, and drinking milk could have been an advantage for lactase-persistent farmers (i.e. in the Neolithic). The fourth, the 'arid climate hypothesis', suggests that in regions where water was scarce, milk could be an uncontaminated source of fluid used by pastoralists. While lactase non-persistent individuals were at risk from diarrhoea and the dehydrating effects of drinking fresh milk, the selection may have been strong in lactase-persistent individuals (for a detailed overview, see Aoki 1986; 2001; Holden, Mace 1997; Bloom, Sherman 2005; Itan et al. 2010; Gerbault et al. 2011; Liebert 2012).

However, archaeological and archaeogenetic data suggest that dairying in Europe was adopted before lactase persistence became frequent. The absence of the allelic variant $-13910^{*} \mathrm{~T}$ shows that lactase persistence in Neolithic populations in Europe was very low and 'may have even been zero' (Leonardi et al. 2012.93). On the contrary, the stable isotope analyses of dairy fats in pottery suggest that milking, milk consumption and processing were widely adopted in the Neolithic. Pastoralism was thus adopted before lactase persistence arose or became frequent. We may assume, therefore, that under normal circumstances lactase persistence is not necessarily to be under very strong selection in this population and fits with the hypothesis that dairying and milk consumption emerged before genetic adaptation. Strong selective pressures may have been episodic and occurred only under certain extreme circumstances, such as drought, epidemic or famine.

\section{The transition to milk culture}

We may assume that animal domestication brought milk into the diet, and that domestic animals were a more stable seasonal resource, which could became an alternative to hunter-gatherers' system of the seasonal exploitation of a broad spectrum of animal resources. Milk is a good source of calories, specifically an important source of protein and fat, and must have increased the quality of the diet. "The milk production of a prehistoric cow has been estimated to range between 400 and $600 \mathrm{~kg}$ per weaning period. Even when the milk necessary for the raising of the calves is subtracted, some 150-250kg remains. This is almost equivalent to the calorie gain from the meat of a whole cow. Hence, over the years, milking may have resulted in a greater energy persistence would have been selected in regions where the disease was frequent. Hence, over the years, milking may have resulted in a greater 
energy yield than the use of cattle for meat" (Gerbault et al. 2011.865-860). Dairying was especially important for children and adolescents as it prolongs the beneficial effects of milk (proteins, fats, but also calcium supply) long after weaning (Vigne 2008.200; Panesar 2011).

Jean-Denis Vigne (2008) suggests that ungulate domestication (e.g., sheep, goat and cattle) in the Near East was part of the diet transition that 'correlates to deep changes in food supply'. It was not because of a better meat supply, but the introduction of milk and milk products that have brought significant modifications to the human diet. Indeed, herd management in the initial Near Eastern Neolithic shows sophisticated herding practices for milk. It implies that large numbers of ovicaprid and bovine female animals were kept; techniques for separately herding young and adults, with particular attention to lambs; and an increase in infant and old-age culling in mortality profiles (Helmer et al. 2007; Vigne, Helmer 2007; Vigne et al. 2011.S266; Cakirlar 2012a; 2012b).

It is worth noting that modern and ancient cattle mtDNA sequences do not support the currently accepted hypothesis of a single Neolithic origin in the Near East. The processes of livestock domestication and diffusion were certainly more complex than previously suggested, and genetic data provide some evidence in favour of the hypothesis that European cattle had multiple origins. Breeds domesticated in the Near East and introduced to Europe during the Neolithic diffusion probably interbred, at least in some regions, with local wild animals and with African cattle introduced by maritime routes. It is possible that pastoralist societies in Southern and Northern Europe used different breeding techniques, with the latter more concerned with herd protection (BejaPereira et al. 2006; see also Edwards et al. 2011).

In addition, stable isotope analyses of dairy fats in pots show evidence of dairy production in southwest Asia as early as $8500 \mathrm{BP}$. The apparent intensification of dairy processing in northwest Anatolia was recognised as an early centre for milk processing, with cow's milk as the main source of dairy products in this region (Evershed et al. 2008; Thissen et al. 2010; for comments see Cakurlar 2012a). This region had a central position in dispersals of Neolithic subsistence economies into Europe (Brami, Heyd 2011; Özdoğan 2011).

On the other hand, Albano Beja-Pereira et al. (2003) suggest that the strong geographic correlation be- tween cattle milk gene diversity, human lactose tolerance and the distribution of the earliest European cattle pastoralists began in North-Central Europe and led to genetic co-evolution between humans and domestic animals, i.e. the ability of adults to consume milk and the ability of dairy cattle to give high milk yields (Beja-Pereira et al. 2003). Allele -13 910*T cline indeed shows frequencies decreasing from North to South. In Scandinavia, where dairying arrived late, almost all the sampled individuals are lactase-persistent, with frequencies ranging between $96 \%$ and $89 \%$. In Southern Europe, it ranges between 15\% and 54\% (Gerbault et al. 2011.864).

The presence of abundant milk fat and specialised vessels used to separate fat-rich milk curds from lactose-containing whey indeed provide direct chemical evidence of milk processing in Northern Europe in the Early Neolithic LBK complex. The pottery assemblage is dated to $c$. 5200 and $4900-4800$ calBC (Salque et al. 2012). Oliver Craig et al. (2005) provided much earlier data for milk processing in the Early Neolithic in Southeast Europe. Degraded ruminant fatty acid in pottery in the Starčevo-Criş (59505500 calBC) and Köros culture (5800-5700 calBC) suggest milk products and milk processing, i.e. the heating of milk.

It should be noted that lactose is progressively reduced by milk processing. The lactose content of fresh milk ranges between $4.42-5.15 \mathrm{~g} / \mathrm{g} \%$ in cattle, $4.66-4.82 \mathrm{~g} / \mathrm{g} \%$ in goats and $4.57-5.40 \mathrm{~g} / \mathrm{g} \%$ in sheep. It can be reduced to $50-60 \%$ by bacterial fermentation. Some processed milk products (such as cheese and butter) have very low lactose content, ranging from $0-3.7 \mathrm{~g} / \mathrm{g} \%$ (Nagy 2011.267; Liebert 2012.77).

Milk is extremely perishable and many methods have been developed to preserve it; fermentation was the earliest method. Inoculating fresh milk with the appropriate bacteria can ferment milk at temperatures that favour bacterial growth. As the bacteria grow, they convert milk sugar or lactose to lactic acid. The lowered $\mathrm{pH}$ caused by lactic acid preserves the milk by preventing the growth of pathogenic bacteria which do not grow well in acidic conditions. The lactic acid bacteria (e.g., Lactobacillus acidophilus, Lactobacillus bulgaricus, Lactobacilus caucasius and Lactococcus lactis) thus turn milk into yogurt, kefir, buttermilk and cheese. They make milk available as a nutritional source throughout the entire life of individuals on the one hand, and allow advantages in storing and transporting dairy 
products and making them available in periods of low milk production on the other.

\section{Lactase persistence and demic diffusion migra- tory model}

Pascale Gerbault et al. (2009; 2011; 2012) and $\mathrm{Yu}-$ val Itan et al. (2009; 2010) intensively studied the evolutionary processes that shaped the European lactase persistence patterns in modern populations. They ran computer simulations to test different selection hypotheses on lactase persistence in relation to demic diffusion and culture diffusion models. Their results are contrasting. Computer simulations showed that high lactase persistence frequencies observed in Northern and Western Europe can be explained by selective pressure, possibly increasing with latitude in a way that is highly compatible with the calcium assimilation hypothesis combined with the effect of demographic expansion (i.e. population growth) during the Neolithic transition. The much lower frequencies in Southeast Europe can be explained by genetic drift if this mutation was carried by Near-eastern pioneers. Keeping in mind that the demic diffusion model is based on the decreasing southeast-northwest cline of frequencies for selected Y-chromosome markers, indicating the movement of Neolithic men with Levantine genetic ancestry across
Europe, it is important to note that the allelic variant -13910 *T cline travels in the opposite direction. However, computer modelling suggests that the centre of distribution of an allele can be far removed from its location of origin in the direction of population expansion, moving at the front of the demic diffusion. This process is called 'allele surfing' and is thought to have occurred with the spread of farmers in Europe (Gerbault et al. 2009.3, 7-8, Fig. 1; 2011; see also Gerbault 2012.179-198, Fig. 4) thus hypothesised that strong selection for lactase persistence runs within the 'niche construction' at the front of the demic diffusion, where local environmental condition and subsistence strategies led to population increase and concentration on milk resources 1 . The initial selection was embedded in Southeast Europe at 8518 \pm 66 BP (7592-7528 calBC), and the first lactase persistent farmers and domesticates arrived in Central Europe and the Northern Adriatic a millennium later, at $7416 \pm 101 \mathrm{BP}$ (6418-6213 calBC) ${ }^{2}$. The latter ${ }^{14} \mathrm{C}$ date was contextualised in the Edera/Stenašca rock shelter in the Trieste Karst and is linked to the Early Neolithic Vlaška culture (Pinhasi et al. 2005.Supporting information, Tab. 1) (Fig. 1).

Nevertheless, Itan et al. (2009; 2010; see also Burger, Thomas 2011; Leonardi et al. 2012) suggest

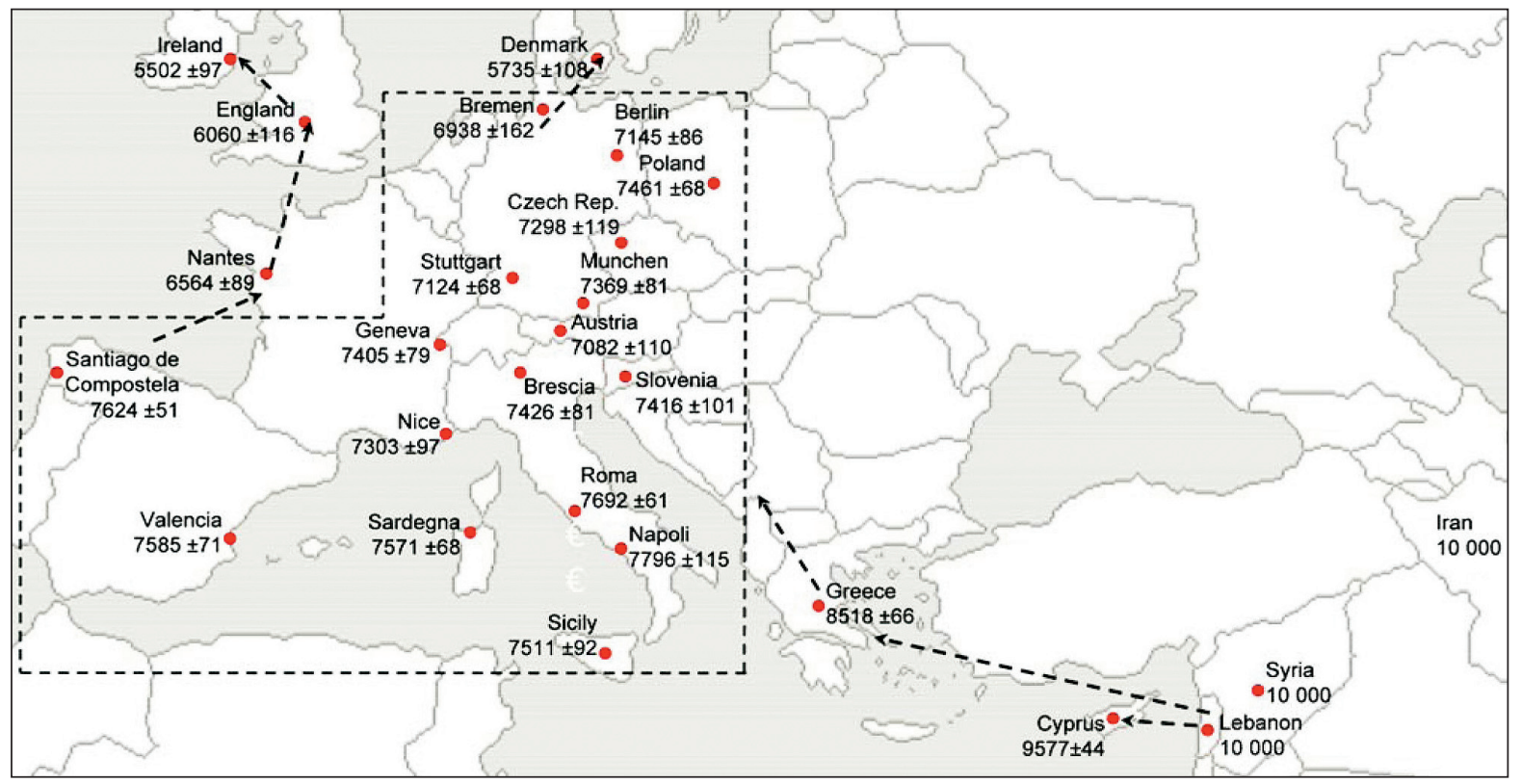

Fig. 1. Map of European and Near-Eastern populations used for the computer simulation test of gene-culture coevolution and calcium assimilation hypotheses of lactase gene selection. It implies that positively selected lactase gene (with frequencies that increase with latitude) was carried over Europe at the front of the Neolithic demic diffusion (from Gerbault et al. 2009.Fig. 1).

1 For discussion that farming niche is not necessary an effective strategy for achieving demographic and economic stability see Rowley-Conwy and Layton (2011).

2 Calibrated with 0xcal 4.2 programme at $1 \sigma$. 
that the $-13910^{*} \mathrm{~T}$ allele first underwent selection in a relatively short period among dairy farmers in the northern Balkans in the Starčevo and Körös cultures. It was than dispersed by demic diffusion to Central and Western Europe in the area of Linear Pottery culture at 'around 6256-8683 years BP' (Itan et al. 2009. 7; see also Itan et al. 2010).

However, both scenarios, the demic diffusion of lactase-persistent farmers across Europe and the evolution of lactace persistence in Central Europe in the Neolithic, seem to be unrealistic. The archaeogenetic analysis of Neolithic skeletons suggests that "lactase persistence frequency was significantly lower in early Neolithic Europeans than it is today, and may have been zero" (Leonardi et al. 2012.93; see also Burger, Thomas 2011). Indeed, the analysis revealed an absence of the $-13910^{*}$ T allele in Central Europe, in the Western Mediterranean and the Baltic in Mesolithic and Neolithic populations (Burger et al. 2007; Burger, Thomas 2011; Lacan et al. 2011; Linderholm 2011; Nagy et al. 2011). The only exceptions are two post-Neolithic individuals in the Basque Country on the Iberian Peninsula (Plantinga et al. 2012).

\section{Early farming and milking in the Caput Adriae (Northern Adriatic)}

The distribution of the first farming communities in the Eastern Adriatic is traditionally associated with the 'Impresso Cardium' (i.e. impressed) pottery dispersal. It was also used as an indicator of the spread of farming across the region. Stašo Forenbaher and Preston Miracle (2005; 2006) introduced a two-phase model suggesting that impressed ware originated in coastal Northern Greece and spread with immigration from South to North along the Adriatic coast. The process included immigrant farmers that made exploratory visits and set up short-term seasonal camps at caves and open-air sites along the coastal strip of southern Dalmatia (i.e. pioneer colonisation), followed by a village settlement that spread slowly towards the Northern Adriatic in areas with fertile soils (i.e. consolidation phase).

The northern boundary of 'Impresso Cardium' pottery through the Eastern Adriatic is positioned in southern Istria, as no early farming sites with im- pressed ware are known from northern Istria and the coastal fringe of the Trieste Bay. Indeed, in most sites across the boundary, the earliest Neolithic is represented by Vlaška pottery (Barfield 1972). These pottery assemblages resemble those from the Middle Neolithic Danilo culture in Dalmatia, and it has been hypothesised that the region was not colonised before the Middle Neolithic (Forenbaher, Miracle 2006; Forenbaher, Kaiser 2006; Biagi, Spataro 2001; Biagi 2003). The Vlaška and Danilo pottery assemblages have similar characteristics in their shapes, decoration techniques and motifs. However, the main difference between them is the absence of painted pottery in Vlaška assemblages.

Nevertheless, we may assume that the Vlaška group does not represent the initial Neolithic in the region. Materialities in stratigraphicaly super-positioned layers $2 \mathrm{a}$ and $3 \mathrm{a}$ at the Edera/Stenašca rock shelter show that the first can be recognised as the Vlaška group, but the latter contained plain pottery of local and non-local manufacture, along with the bones of domestic (i.e. caprines, cattle and pig) and wild animals, shells of marine molluscs and lithics that includes trapezes and microburins. It was recognised as a Late Castelnovian hunter-gatherer complex and dated to $6700 \pm 130 \mathrm{BP}(5700-5515 \mathrm{calBC})$ (Biagi, Spataro 2001.35).

The beginning of the Early Neolithic in the Eastern Adriatic appears to be embedded in the time span between 6048-5988 calBC in the North (Vela spilja, Mali Lošinj island), 5985-5843 calBC in the central region (Pokrovnik in Dalmatia), and between 59865903 calBC (Spila Nakovana on Pelješac peninsula) and 5989-5767 (Vela spila on Korčula Island) in the South3. The available ${ }^{14} \mathrm{C}$ evidences in the Northern Adriatic show that the Istrian peninsula and Karst Plateau above Trieste Bay remained outside this range. It is postulated that the Neolithic was established here at $c .5600$ calBC and that it was associated with the end of "Impressed Ware and the appearance of assemblages with only undecorated pottery" (i.e. Vlaška-Danilo pottery) in the Middle Neolithic (Forenbaher et al. 2013.599) (Fig. 2).

Interestingly, Mesolithic sites are known in this area (Komšo 2006), but none is securely dated to the pe-

\footnotetext{
3 The recently published ${ }^{14} \mathrm{C}$ dates are: $7134 \pm 37$ BP (0xA-18118) for Vela spilja, Mali Lošinj Island; $7000 \pm 100$ BP (lab code unavai-

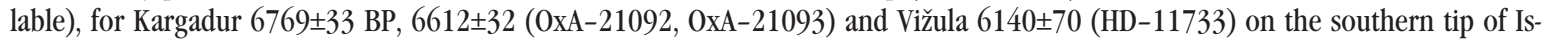

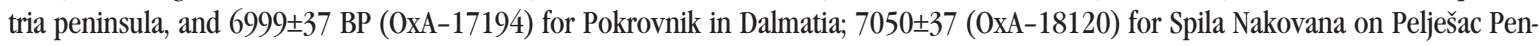
insula; and 7000 120 (Z-1968) for Vela spila (Bonsal et al. 2013.149, Tab. 8.1; Forenbaher et al. 2013.Tab. 1). A date from Vela spila, originally published as related to early 'Impresso Cardium' pottery $7300 \pm 120 \mathrm{BP}, \mathrm{Z}-1967$ ), has recently been reattributed to a 'Mesolithic/Neolithic transitional period' (Forenbaher et al. 2013.597). The dates are calibrated at 68.2 probability using the Oxcal 4.2 program.
} 
riod after 6000 calBC. On the other hand, radiocarbon sequences from sites in this region show a temporal gap between the latest Mesolithic and earliest Neolithic occupations that varied in duration and were not synchronous among the sites, although there is an evident continuity of occupation over the wider region. Various hypotheses have already been proposed to account for the temporal discontinuity, but it remains unresolved (for discussions, see Biagi, Spataro 2001; Biagi 2003; Forenbaher, Miracle 2006.497-504; Mlekuž et al. 2008; Berger, Guilaine 2009; Bonsall et al. 2013).

\section{How the Neolithic Vlaška group herders mana- ged ovicaprids}

The question of how the Neolithic Vlaška group herders managed herds has been addressed already. Most authors agree that Vlaška group herders were involved in some form of transhumant or nomadic pastoralism, with seasonal occupation of cave sites (Miracle, Pugsley 2006; Mlekuž 2005). However, contradictory scenarios have been proposed based on the interpretation of kill-off curves (see RowleyConwy 2013.163-174).

It is worth remembering that Sebastian Payne (1973) proposed - on the basis of his ethnoarchaeological research among Turkish pastoralists - a middle range theory, which links flock management strategies to kill-off curves. It is based on the assumption than an optimisation of animal products can be obtained by manipulating the sex and age structure of the herd. Ideal dairying and meat models differ in the age when males are culled. In the ideal dairying model, most animals younger than two months are culled in order to reduce competition for milk with people. With an optimal meat strategy, most animals are culled after one to three years, as they achieve their maximum weight.

The interpretation of kill-off curves is complicated by a strong preservation bias against neonates and young animals on the one hand and a high natural mortality of neonates and young animals on the other. But the main problem behind the use of idealised curves is the assumption that people in the past behaved optimally. Ethnographic evidence suggests that within household-based economies, animals are used for a variety of animal products. Specialised and optimised exploitation of animal products emerges from the demands of a market-based economy. Thus, a correspondence to the ideal 'dairying' model

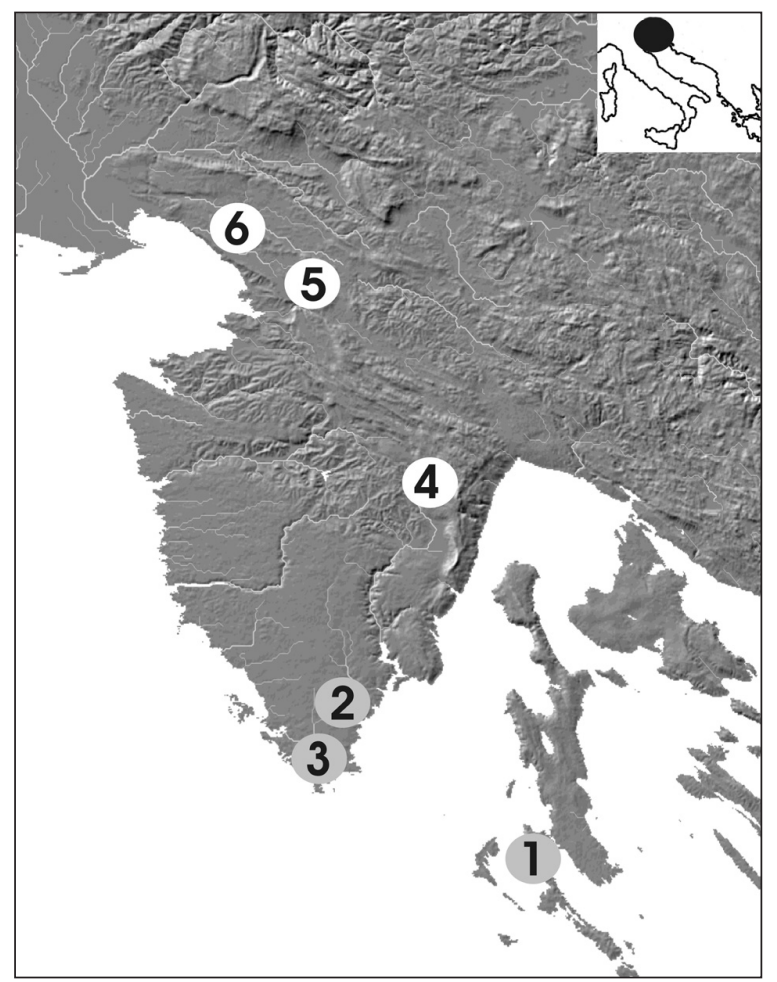

Fig. 2. The Impresso cardium culture (grey dots) and Vlaška culture (white dots) sites distribution in Caput Adria mentioned in text. 1 Vela spilja; 2 Kargadur; 3 Vižula; 4 Pupićina pećina; 5 Mala Triglavca; 6 Edera/Stenašca.

would indicate specialised production geared towards exchange (Halstead 1996.25; 1998).

Two new models for detecting animal exploitation for meat and milk have been proposed recently ( $\mathrm{Vi}$ gne, Helmer 2007; Vigne 2008). They suggest that caprine and cattle culling profiles in the Near East and the Mediterranean show that the exploitation of cattle, sheep and goats was aimed at milk production and not only meat from the initial Neolithic onwards. While small herds of goats were exploited mainly for milk, larger sheep herds were also for meat production. However, no curve resembles ideal strategies based on either meat or milk.

Vlaška group bone assemblages are comprised predominately of sheep and goat bones (around $60 \%$ of sheep and goats and less than $10 \%$ of cattle; see $\mathrm{Mle}$ $k u z ̌ 2005$ ). Milk yields from small stock are generally much lower than those of cows (goats, which have up to $100 \%$ higher yields than sheep, typically produce around $125 \mathrm{~kg}$ of milk per lactation); however, they have a very high rate of increase (up to ten times compared to cattle). This makes them especially suitable for the accumulation of large herds (see Ingold 1980; Dahl, Hjort 1976; Mlekuž 2005). 
Kill-off curves from the North Adriatic region (Miracle, Forenbaher 2005; Miracle, Pugsley 2006. 319-335, Fig. 7.27) were interpreted as a result of the management of herds aimed at harvesting dairying products. Dimitrij Mlekuž (2005; 2006), on the contrary, suggested that kill-off curves demonstrate a relatively simple, non-optimised economy aimed primarily at the domestic consumption of meat, not strategies aimed at maximising dairy products (Fig. 3). However, this does not exclude small-scale dairying of sheep and goats. Since goats are more effective milk producers than sheep (Dahl, Hjort 1976. 210), one would assume that goats were milked (Rowley-Conwy 2000). Goats are present after the appearance of small stock in Caput Adriae. However, their proportion compared to sheep is relatively low, around $20 \%$, rendering their role in small-scale dairying invisible in the crude resolution of survivorship curves.

\section{Molecular and isotope evidence of dairying and food processing in the Caput Adriae: Mala Tri- glavca case study}

We present the results of the organic residues analyses of pottery deposited in a stratified deposit at the Mala Triglavca rockshelter. The site is located on the Dinaric Karst in south-western Slovenia, $15 \mathrm{~km}$ from the Northern Adriatic coast (Fig. 2). The site is still being excavated, but the pilot molecular and isotope analyses have already shown well-preserved lipid residues and the presence of dairy products ( $\check{S}_{0}$ berl et al. 2008). The AMS ${ }^{14} \mathrm{C}$ dates show a long sequence of human agency from the $8^{\text {th }}$ to the $3^{\text {rd }}$ millennium calBC, combined with post-depositional disturbances of natural and geomorphological processes (Mlekuž et al. 2008) (Fig. 4).

The evidence from the current excavations and associated soil/sediment analyses show that in the central part of the cave a well-defined stratigraphic sequence can be established, despite post-depositional modifications by soil-forming processes. There is, however, evidence of post-depositional disturbances of cave sediments by human agency and geological/ geomorphological processes such as rotational slumps, as verified by the presence of distinct shear planes near the cave wall.

The sequences in the central part of the rock shelter consist of a series of thin white powdery layers interleaved with darker layers. This rhythmic depositional sequence can be interpreted as a series of occupation levels. Each occupation started with the

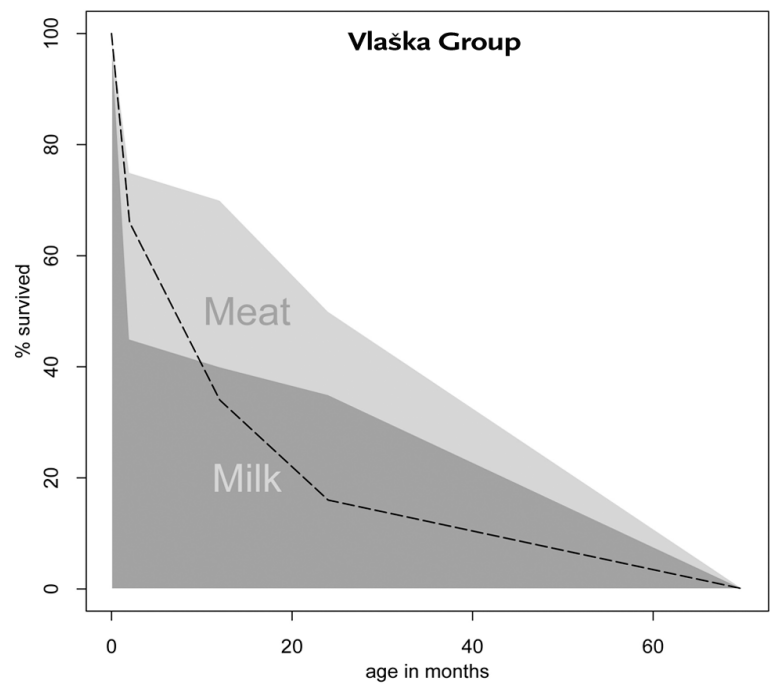

Fig. 3. Combined kill-off curve from Caput Adriae Vlaška assemblages (Grotta dell'Edera/Stenašca, Grotta degli Zingari/Ciganska jama, Grotta del Mitreo/Mitrej and Grotta dei Ciclami/Orehova pejca; see Mlekuž 2006). Sample size is 60 dentitions.

preparation of a new floor, sometimes by using large platy stones to cover the previous heap of ash. Irregularities and depressions were filled with stones, so that the floors in the rock shelter were kept horizontal. At the end of occupation, organic debris was cleaned and the collected material heaped and burned; the result is a new heap of ash.

Nevertheless, there are some differences between occupational levels. The quantity of the deposited material varies vastly between levels. Some occupation levels are very simple, while others are quite elaborate, with well-paved surfaces made from large platy stones. In some levels, we have evidence of vertical elements that were part of the occupation floor. Thus, we have found several elaborately built circular stone structures. We have identified 25 occupation episodes so far, embedded in the time span of $c .5800$ calBC (level 19) and c. 3500 calBC (level 1) so far (Tab. 1; Fig. 4).

The Neolithic and Eneolithic pottery assemblage of occupational levels 1 to 23 is comprised mostly of various types of bowls, but beakers, dishes and pots are also present, and most of these have a simple outline (Tab. 1; Fig. 5). According to their shape and decoration, most of the vessels from occupational level 6 onwards can be linked to the Vlaška pottery group as described by Lawrence Barfield (1972). The oldest pottery fragments appear as early as 5616-5525 calBC and have the same technological characteristics as the typical Vlaška pottery at the site, i.e. with local clays prepared with added cru- 
shed calcite (Žibrat Gašparič 2004). On the other hand, these oldest pottery fragments were mostly polished and undecorated, i.e. they do not exhibit typical Vlaška decorations.

We tested the hypothesis that dairying was an integral part of a mixed subsistence strategy from the initial Neolithic onwards by examining a range of pottery from the site. For the lipid analysis, we sampled 29 vessels from Mala Triglavca from contexts ranging from 5467-5356 to 4338-4261 calBC (Fig. 5; Tabs. 1 and 2). The samples were chosen accord- ing to their stratigraphic position, typology and decoration characteristics. The majority of samples $(83.3 \%)$ are various types of bowls with incised ornaments or appliqués typical of the Vlaška group. The remaining samples were two pots and two deep dishes. The samples are all made of fabrics with added calcite grains as temper and are mostly fine-grained (75\%), very fine-grained (20.8\%); only one sample had a coarser-grained temper. The surfaces of the vessels were mostly burnished (54.2\%) and polished (29.3\%); smoothing is less common (16.7\%). The surface colour of the vessels is predominantly light brown

\begin{tabular}{|c|c|c|c|c|c|}
\hline $\begin{array}{l}\text { Occupation } \\
\text { level }\end{array}$ & Structures & Predominant types of food & $\begin{array}{l}\delta^{13} C_{\text {bulk }} \pm 0.2 \\
(\% \circ)\end{array}$ & $\begin{array}{l}\text { Radiocabon } \\
\text { date }\end{array}$ & Lab code \\
\hline 1 & & & & $3690 \pm 40 *$ & Poz-15343 \\
\hline \multicolumn{6}{|l|}{2} \\
\hline \multicolumn{6}{|l|}{3} \\
\hline \multicolumn{6}{|l|}{4} \\
\hline \multicolumn{6}{|l|}{5} \\
\hline 6 & & freshwater fish (MaTr470) & $-25,7$ & & \\
\hline \multicolumn{6}{|l|}{7} \\
\hline 8 & & & & $5530 \pm 60$ & Beta-23604 \\
\hline 9 & & $\begin{array}{l}\text { dairy (87MT)***; ruminant } \\
\text { adipose fat (MaTr151) }\end{array}$ & MaTr151: $-28,0$ & $6960 \pm 170 * * ;$ & Poz-48531 \\
\hline 10 & & $\begin{array}{l}\text { dairy }(\mathrm{MaTr} 130, \mathrm{MaTr} 137) ; \\
\text { ruminant adipose fat } \\
\text { (MaTr112, MaTr115, MaTr116) }\end{array}$ & $\begin{array}{l}\text { MaTr130: }-27,8 \\
\text { MaTr137: }-27,0 \\
\text { MaTr112: }-25,6 \\
\text { MaTr115: }-26,4 \\
\text { MaTr116: }-24,9 \\
\end{array}$ & $6390 \pm 40$ & Poz-48530 \\
\hline \multicolumn{6}{|l|}{11} \\
\hline 12 & & ruminant adipose fat (MaTr147) & $-26,6$ & $6320 \pm 40 *$ & Poz-21395 \\
\hline 13 & & $\begin{array}{l}\text { ruminant adipose fat (MaTr159); } \\
\text { mixed, plant (MaTr145) }\end{array}$ & $\begin{array}{l}\text { MaTr159: }-26,0 \\
\text { MaTr145: }-26,2\end{array}$ & $5660 \pm 40 * *$ & Poz-48543 \\
\hline 14 & postholes & $\begin{array}{l}\text { dairy (79MT, 161MT) } \\
\text { (MaTr53); mixed, plant (MaTr107) mixed }\end{array}$ & $\begin{array}{l}\text { MaTr53: }-25,4 \\
\text { MaTr107: }-26,3\end{array}$ & $6340 \pm 40$ & Poz-48539 \\
\hline 15 & circular structure & $\begin{array}{l}\text { dairy (MaTr174); ruminant } \\
\text { adipose fat (MaTrı73, MaTr6oo) }\end{array}$ & $\begin{array}{l}\text { MaTr174: }-26,5 \\
\text { MaTr173: }-25,9 \\
\text { MaTr6oo: }-26,0\end{array}$ & $6940 \pm 40 * *$ & Poz-48542 \\
\hline 16 & & mixed $(159 \mathrm{MT}) * * * *$ & & & \\
\hline 17 & & & & $6400 \pm 40$ & Poz-48541 \\
\hline 18 & & & & $6410 \pm 40$ & Poz-48538 \\
\hline 19 & circular structure & $\begin{array}{l}\text { dairy (MaTr6o2); freshwater fish } \\
\text { (MaTr599); mixed, } \\
\text { plant (MaTr6o6) }\end{array}$ & $\begin{array}{l}\text { MaTr6o2: }-26,3 \\
\text { MaTr599: }-25,4 \\
\text { MaTr6o6: }-23,0\end{array}$ & $6620 \pm 40$ & Poz-48540 \\
\hline \multicolumn{6}{|l|}{20} \\
\hline \multicolumn{6}{|l|}{21} \\
\hline \multicolumn{6}{|l|}{22} \\
\hline 23 & $\begin{array}{l}\text { posthole, circular } \\
\text { structure }\end{array}$ & & & & \\
\hline 24 & posthole & & & & \\
\hline $\begin{array}{l}* \text { Date from } \\
* * \text { Stratigrap } \\
* * \text { Stratigrap }\end{array}$ & $\begin{array}{l}\text { Leben's excavations } \\
\text { ic/ }{ }^{14 C} \text { inconsistency } \\
\text { ic position based in c }\end{array}$ & lation with Leben's excavated levels. & & & \\
\hline
\end{tabular}

Tab. 1. The composite table presenting the occupational levels at Mala Triglavca, the AMS 14 C dates and the lipid residues from pottery. 
$(41.7 \%)$ and brown (20.8\%), but dark brown, greyish black, light red and yellow surface colours are also present. The vessels were mostly fired in an incomplete oxidising atmosphere (54.2\%), but some samples were also fired in an oxidising and a reducing atmospheres.

Various types of decoration were present in $45.8 \%$ of the samples, but most of the vessels are undecorated (54.2\%). The decoration techniques included incisions, appliqués and rare impressions, or a combination of these techniques. The motifs include: a band of hatched pendant triangles (samples MaTr112, MaTr470; Fig. 5.3), which is the most typical motifs of the Vlaška group (Barfield 1972.202, Taf. 50.8-11); a curvilinear garland motif (sample MaTr115; Fig. 5.2) and a plant motif (sample MaTr130; Fig. 5.4). The plant motif is rare in the Caput Adriae region, but appears mostly on typical Vlaška bowls (Barfield 1972.202, Taf. 50. 15). Similar decorations are known from the Trieste Karst area, such as on a bowl from layer 5 at Grotta degli Zingari/Ciganska jama (Gilli, Montagnari Kokelj 1996.79, Fig. 16.72) and on pottery from Grotta dei Ciclami/Orehova pejca (Gilli, Montagnari Kokelj 1992(1993). 75, Fig. 10.57, 63, Fig. 11.65), but also from the Danilo culture site of Pokrovnik in Dalmatia (Müller 1994.Taf. 9.5). The garland motif is similar to a bowl with a curvilinear, incised decoration from Vlaška jama/ Grotta del Pettirosso (Barfield 1999.Fig. 3.21), the eponymous site for the characterisation of the Vlaška group, and a similar decoration on a bowl is also known from Neolithic layer 5 of Grotta degli Zingari/Ciganska jama (Gilli,
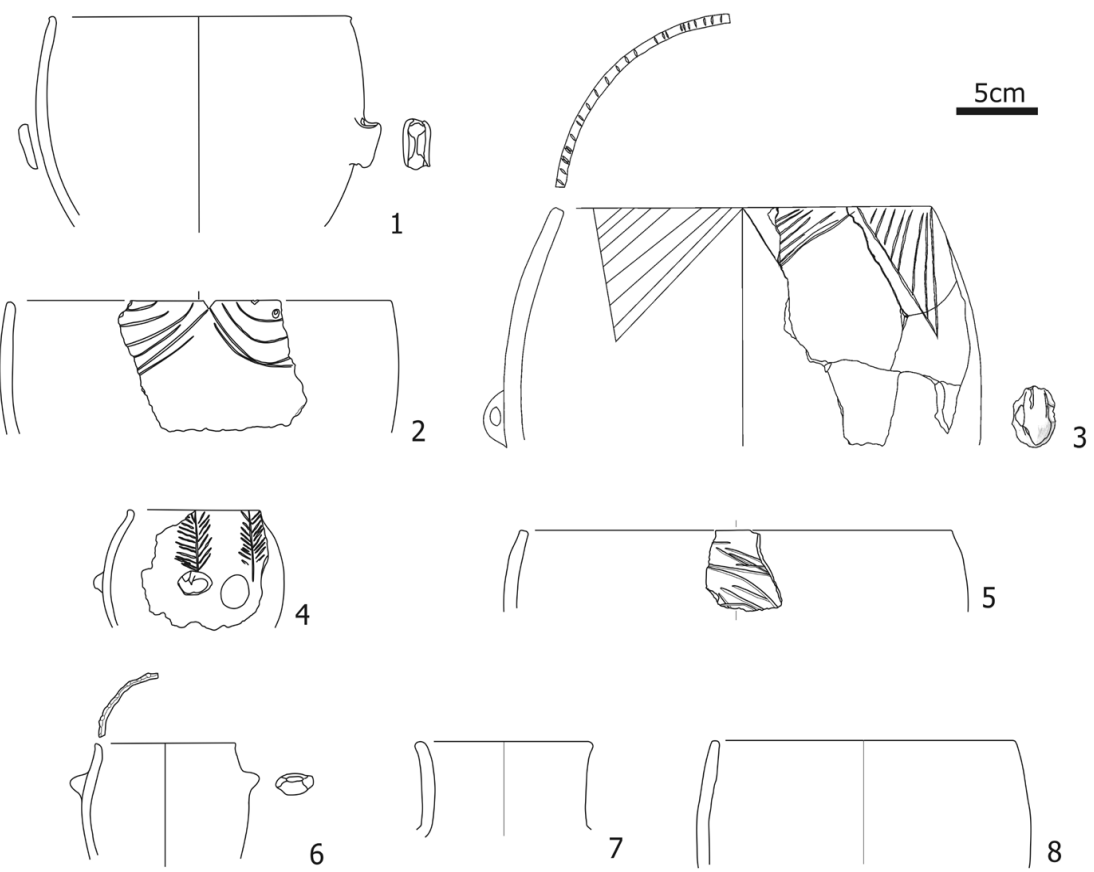

Fig. 5. Selected pottery samples for organic residue analysis from Mala Triglavca. 


\begin{tabular}{|c|c|c|c|c|c|c|c|c|c|c|c|c|c|c|c|c|c|c|c|c|c|c|c|c|c|c|c|}
\hline 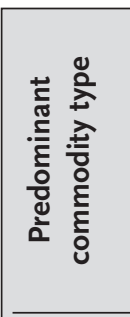 & 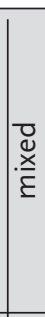 & $\begin{array}{l} \\
\\
\vec{x} \\
\underline{\varepsilon} \\
\end{array}$ & 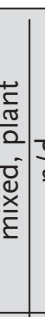 & 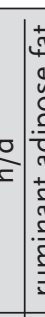 & 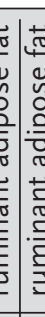 & & & & & $0^{\circ}$ & & 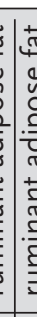 & & 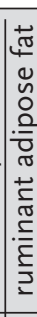 & & & & & & & $\left|\begin{array}{c}\mathrm{t} \\
\frac{\pi}{0} \\
0 \\
0 \\
0 \\
0\end{array}\right|$ & $\frac{\widehat{x}}{\pi}$ & & $\frac{\partial}{x}$ & . & 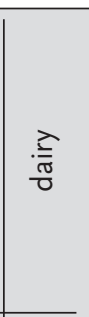 & \\
\hline 离 & 岁 & & 岁 & & 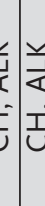 & 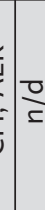 & & & & t) & & $\begin{array}{l}\mathrm{T} \\
\mathrm{C} \\
\mathrm{y}\end{array}$ & & & & $\frac{\check{Z}}{\vec{\alpha}}$ & & $\frac{\pi}{4}$ & $\frac{\delta}{c}$ & & $=\frac{\mathrm{y}}{\mathrm{d}}$ & $\begin{array}{l}I \\
O \\
\check{I} \\
\stackrel{\bar{\Psi}}{L} \\
\text { İ }\end{array}$ & & & I & $\frac{0}{x}$ & \\
\hline 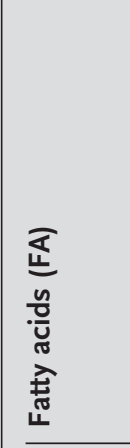 & 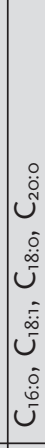 & 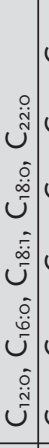 & |نَّ. & & 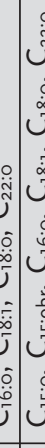 & 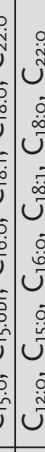 & & & $\stackrel{\cup}{\sim}$ & U. & 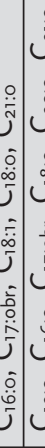 & 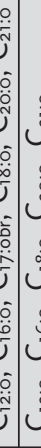 & & 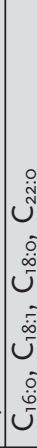 & & $\stackrel{\infty}{\dot{\omega}}$ & 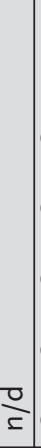 & |ü. & ك) & كُ & 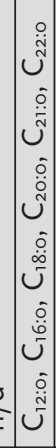 & 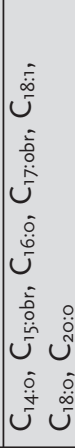 & 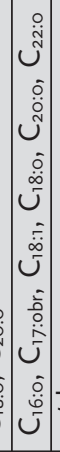 & 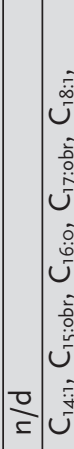 & 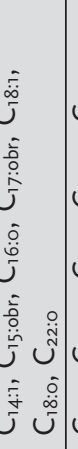 & 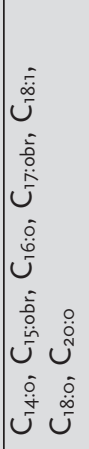 & শ্ \\
\hline 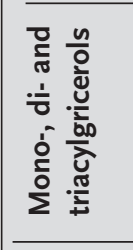 & $\frac{\pi}{5}$ & & & & & U & & & & & 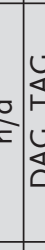 & & & 0 & & & 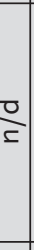 & $\frac{0}{c}$ & & & $=\frac{0}{x}$ & 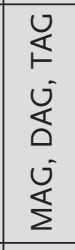 & & \begin{tabular}{|l|l}
$\frac{0}{x}$ \\
$\vdots$ \\
$\vdots$
\end{tabular} & 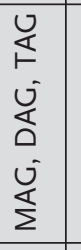 & 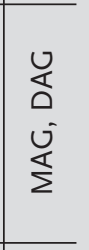 & 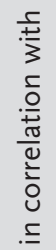 \\
\hline نْ نْن & $\dot{i}$ & 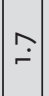 & $\stackrel{\leftrightarrow}{\square}$ & $\frac{0}{c}=$ & $=\infty$ & 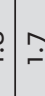 & & & i & 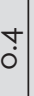 & t? & & & . & & 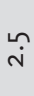 & $\frac{0}{c}$ & & I & . & $\begin{array}{l}\varphi \\
\dot{m}\end{array}$ & $\frac{0}{x}$ & $\stackrel{0}{-}$ & $\frac{\pi}{2}$ & $\frac{\sigma}{x}$ & $\frac{0}{x}$ & \\
\hline 抎 & 울 & $\begin{array}{c}\infty \\
\dot{i} \\
i\end{array}$ & $\begin{array}{l}\infty \\
0 \\
i\end{array}$ & $5:$ & 7 & 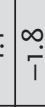 & & & 8 & & $T$ & & 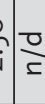 & مُ & & 15 & $\tau$ & ○ & & & $=\left[\begin{array}{c}0 \\
⿱ 亠 乂 \\
0 \\
0\end{array}\right.$ & $\tilde{i}$ & & $\frac{0}{2}$ & o. & $\bar{i}$ & \\
\hline 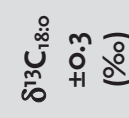 & $\tilde{\tilde{T}}$ & $\stackrel{P}{\Upsilon}$ & $\dot{m}$ & & 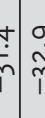 & $\stackrel{m}{m}$ & & & r & $\underset{m}{N}$ & 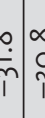 & & - & & & & $\frac{0}{c}$ & 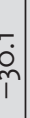 & & $\dot{j} \tau$ & $=\mid \begin{array}{l}\hat{0} \\
\tilde{T}\end{array}$ & $\dot{\bar{r}}$ & & $\frac{0}{x}$ & $\stackrel{\infty}{i}$ & 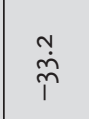 & \\
\hline 兽 & $\tilde{\imath}$ & $\left|\begin{array}{l}0 \\
\dot{\sim} \\
i\end{array}\right|$ & $\stackrel{m}{n+1}$ & $\frac{i}{0}$ & $\dot{s}$ & $\mid \frac{\dot{\vec{\pi}}}{\dot{\pi}}$ & & & N & $\bar{j}$ & c & Si & - & & & & ס & $\mathrm{j}$ & & & $=\mid \begin{array}{l}0 \\
\dot{\rho} \\
i\end{array}$ & $\stackrel{\hat{i}}{i}$ & $\left|\begin{array}{c}m \\
\hat{i} \\
i\end{array}\right|$ & $\frac{\mathrm{D}}{\mathrm{r}}$ & 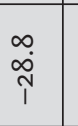 & $\stackrel{\substack{\infty \\
i}}{i}$ & $\stackrel{\therefore}{\because}$ \\
\hline 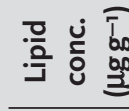 & & ָ̇ं & $\overline{\dot{y}}$ & مُ & 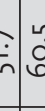 & $\stackrel{\sim}{\infty}$ & & & $\vec{i}$ & & & & & ִִ. & & & ભે. & & 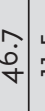 & & 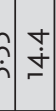 & $\stackrel{\circ}{\dot{m}}$ & $\mid \begin{array}{l}9 \\
\dot{0} \\
\hat{n}\end{array}$ & $\begin{array}{l}0 \\
\dot{0} \\
\stackrel{-}{-}\end{array}$ & $\stackrel{\stackrel{\varphi}{\dot{r}}}{ }$ & 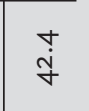 & స્へ \\
\hline 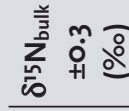 & $\stackrel{\leftrightarrow}{\dot{r}}$ & 它 & $\frac{0}{5}$ & $\frac{0}{5}$ & $=0$ & t. & & & o & & & & & & & & & & & $\tau$ & $=\overline{0}$ & $\frac{0}{x}$ & $\frac{0}{\Omega}$ & $\frac{0}{2}$ & $\frac{0}{x}$ & $\frac{0}{a}$ & $\frac{\text { กे }}{\dot{0}}$ \\
\hline 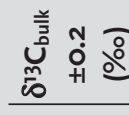 & it & 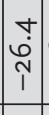 & ֻُ & $\begin{array}{lll}0 & 5 \\
2 & \\
2\end{array}$ & 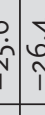 & 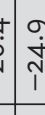 & & & & & & & & & & & & & & & $\begin{array}{l}N \\
1 \\
\end{array}$ & $\frac{0}{x}$ & $\frac{0}{\Omega}$ & $\frac{0}{2}$ & $\frac{0}{x}$ & $\frac{0}{x}$ & 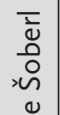 \\
\hline $\begin{array}{l}\text { uo! } \\
\text {-7d!ussəa }\end{array}$ & \begin{tabular}{|l} 
\\
\\
\end{tabular} & \begin{tabular}{|l|} 
\\
0 \\
0 \\
\end{tabular} & $\frac{5}{\bar{n}}$ & 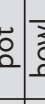 & - & $\begin{array}{l}3 \\
0 \\
0\end{array}$ & & & & & & & & & & & & & & & \begin{tabular}{|l|}
3 \\
0 \\
0 \\
\end{tabular} & $\begin{array}{l} \\
\\
\end{array}$ & 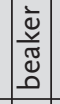 & 总 & مु & $\overline{3}$ & J \\
\hline pex & \pm & & 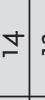 & r & 9 & $\stackrel{\circ}{\circ}$ & & & & & & & & & & & & & & & $\sigma$ & 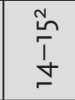 & \begin{tabular}{|l|}
0 \\
0 \\
0 \\
$\infty$
\end{tabular} & 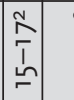 & $\stackrel{\llcorner}{\sim}$ & 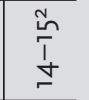 & 离 \\
\hline ْึ & $=$ & 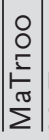 & & $\frac{\pi}{2} \frac{5}{2}$ & & & & & & & & & & & & & & & & & & $\sum_{\Omega}^{5}$ & $\left|\sum_{\infty}^{F}\right|$ & 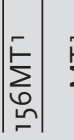 & 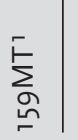 & 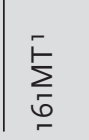 & $\begin{array}{l}\frac{\tilde{\omega}}{0} \\
\tilde{\varepsilon}_{\tilde{\sigma}} \\
\sim\end{array}$ \\
\hline
\end{tabular}


remove any exogenous lipids. The sub-samples were then ground to a fine powder. In addition, fat samples of modern cattle, sheep and cow that have been fed exclusively on $\mathrm{C} 3$ forage grasses on the Karst plateau were analysed in order to test the origin of the fat in the archaeological ceramics (Tab. 3).

First, powder samples were analysed by elemental analysis isotope ratio mass spectrometry (IRMS) using Europa Scientific IRMS with an ANCA-SL preparation module for solid and liquid samples (PDZ Europa Ltd, Crewe, UK) as previously reported ( $O g$ rinc et al. 2012). Each sample was acidified using $1 \mathrm{~N} \mathrm{HCl}$ to remove carbonate minerals and dried. Stable isotope results are expressed as $\delta^{13} \mathrm{C}$ or $\delta^{15 \mathrm{~N}}$ values in per mil (\%) relative to the VPDB and AIR international standard, respectively. The precision of measurements was $\pm 0.2 \%$ o for $\delta 13 \mathrm{C}$ and $0.3 \%$ o for $\delta 15 \mathrm{~N}$.

The powdered material ( $2 \mathrm{~g}$ sample) is then extracted by ultrasonication with an organic solvent (e.g., chloroform/methanol, 2:1 v/v) and evaporated to dryness under a gentle stream of nitrogen to obtain the total lipid extract (TLE). One portion of extract was trimethylsilylated directly and analysed by hightemperature gas chromatography (HT GC) and where necessary combined gas chromatography/mass spectrometry (GC-MS) analyses were performed to identify the structure of components (Evershed et al. 1990). Further aliquots of the TLE were methylated using BF3/methanol to obtain fatty acid methyl esters (FAMEs) (14\%, w/v; $100 \mu$; Sigma Aldrich, Gillingham, UK; at $70^{\circ} \mathrm{C}$ for $1 \mathrm{~h}$ ). The methyl ester derivatives were extracted with hexane and the solvent removed under nitrogen. FAMEs were re-dissolved in hexane for analysis by GC and GC-combustion-isotope ratio MS (GCC-IRMS) using standard protocols (Evershed et al. 1994; Mottram et al. 1999; Greg, Slater 2010; Ogrinc et al. 2012). GC-C-IRMS analyses were performed using an Isoprime GV system (Micromass, Manchester, UK). Modern samples were extracted by the same procedure. For GC-C-IRMS, the precision on repeated measurements was $0.3 \%$.
The third TLE aliquot was used to identify the di- and triacylglycerol (DAG, TAG) content, following the procedure described by Sigrid Mirabaud et al. (2007). TAG analyses were performed by hybrid quadruple time of flight mass spectrometer (Q-TOF Premier) provided with an orthogonal Z-spray ESI interface (ESI-MS; Waters Micromass, Manchester, UK) (Ogrinc et al. 2012).

\section{The bulk $C$ and $N$ isotope composition}

The determination of the isotopic composition of carbon (C) and nitrogen (N) was possible in 19 samples. The average and standard deviation from potsherd samples are $-26.1 \pm 1.1 \%$ ond $+6.8 \pm 2.9 \%$ for $\delta^{13} \mathrm{C}$ and $\delta^{15} \mathrm{~N}$, respectively (Tab. 2). These data fall in the range expected for degraded animal and plant tissues whose subsistence was based mainly on $\mathrm{C} 3$ plants. The $\delta^{15} \mathrm{~N}$ values show greater variations compared to the $\delta 13 \mathrm{C}$ values.

We could discriminate three groups of samples on the basis of their $\delta^{15} \mathrm{~N}$ and $\Delta^{13} \mathrm{C}$ values (i.e. $\delta^{13} \mathrm{C}_{18: 0}$ $-\delta^{13} \mathrm{C}_{16: 0}$ ). The first group has the highest $\Delta^{13} \mathrm{C}$ values of $>2.0 \%$ and were found in two samples (MaTr470 and MaTr599). Freshwater fish is the most likely component of residuals with the highest $\delta 15 \mathrm{~N}$ value of $+10.3 \%$ in sample MaTr470, while the 1ower value of $+8.4 \%$ o could indicate the presence of molluscs and crustaceans in sample MaTr599. The second group with $\delta 15 \mathrm{~N}$ values between +0.1 and $+5.4 \%$ and $\Delta 13 \mathrm{C}$ values of around $0 \%$ shows that these pots were probably used to process herbivore products and/or plant material (MaTr53, MaTr100,

\begin{tabular}{|lcccl|}
\hline Sample & $\begin{array}{c}\boldsymbol{\delta}^{13} \mathbf{C}_{16: 0} \\
\pm \mathbf{0 . 3}(\%)\end{array}$ & $\begin{array}{c}\mathbf{\delta}^{13} \mathbf{C}_{18: 0} \\
\pm \mathbf{0 . 3}(\% \circ)\end{array}$ & $\begin{array}{c}\Delta^{13} \mathbf{C} \\
(\% \circ)\end{array}$ & Location / citation \\
\hline Sheep milk & $-30,2$ & $-36,2$ & $-6,0$ & Divača Karst, local \\
\hline Goat milk & $-27,2$ & $-32,6$ & $-5,4$ & Divača Karst, local \\
\hline Cow milk & $-29,6$ & $-37,5$ & $-7,9$ & Divača Karst, local \\
\hline Sheep curd & $-27,2$ & $-32,1$ & $-4,9$ & Divača Karst, local \\
\hline Sheep cheese & $-27,6$ & $-32,3$ & $-4,7$ & Divača Karst, local \\
\hline Sheep milk & $-33,2$ & $-39,0$ & $-5,8$ & Spangenberg et al. 2006.7-8, Fig. 4 \\
\hline Sheep milk & $-33,2$ & $-39,9$ & $-6,7$ & Spangenberg et al. 2006.7-8, Fig. 4 \\
\hline Sheep milk & $-33,0$ & $-40,0$ & $-7,0$ & Spangenberg et al. 2006.7-8, Fig. 4 \\
\hline Sheep milk & $-33,9$ & $-41,0$ & $-7,1$ & Spangenberg et al. 2006.7-8, Fig. 4 \\
\hline Cow milk & $-29,6$ & $-34,6$ & $-5,0$ & Richter et al. 2012a. 911, Tab. 3 \\
\hline Goat milk & $-27,2$ & $-34,0$ & $-6,8$ & Spangenberg et al. 2006.7-8, Fig. 4 \\
\hline Goat milk & $-28,0$ & $-35,0$ & $-7,0$ & Spangenberg et al. 2006.7-8, Fig. 4 \\
\hline Sheep cheese & $-30,8$ & $-35,8$ & $-5,0$ & Spangenberg et al. 2006.7-8, Fig. 4 \\
\hline Sheep cheese & $-29,8$ & $-35,5$ & $-5,7$ & Spangenberg et al. 2006.7-8, Fig. 4 \\
\hline Goat cheese & $-26,5$ & $-30,5$ & $-4,0$ & Spangenberg et al. 2006.7-8, Fig. 4 \\
\hline
\end{tabular}

Tab. 3. Means for stable carbon isotope composition of $C_{16: 0}$ and $C_{18: 0}$ in different dietary components of modern reference animal fats. 
MaTr151, MaTr606). The $\Delta 13 \mathrm{C}$ values of the third group of samples indicate the presence of ruminant adipose and dairy fats (MaTr107, MaTr112, MaTr115, MaTr116, MaTr130, MaTr137, MatR145, MaTr147, MaTr159, MaTr173, MaTr174, MaTr600, MaTr602, 79MT, 87MT, 159MT, 161MT); and the $\delta 15 \mathrm{~N}$ values ranged from +5.4 to $+9.7 \%$. It should be noted that the $\delta^{15} \mathrm{~N}$ values of protein from terrestrial herbivores from temperate environments in Europe should not exceed 7.0\%o (Richards et al. 2003). However, the protein derived from domestic animals can be higher (Privat et al. 2002; Polet, Katzenberg 2003; Richards et al. 2003; Ogrinc, Budja 2005). As most of the $\delta 15 \mathrm{~N}$ values of our samples are higher than $+7.0 \%$, we hypothesise that the protein derived mainly from domestic animals.

The evidence of processing of dairy and other animal and/or plant products in pottery vessels was further investigated by lipid analysis. Lipid preservation was very good, with more than $80 \%$ of potsherds yielding an appreciable lipid concentration (Tab. 2).

\section{Processing of dairy and other animal products}

DAG and TAGs are indicative lipids of degraded animal fats and could help to differentiate between fats of ruminant and non-ruminant animals and ruminant dairy fats (Kimpe et al. 2002; Mirabaud et al. 2007; Regert 2011). The TAG analysis of modern fats exhibits two main distributions of TAGs: a narrow one that corresponds to non-ruminant adipose fats, and a broad one ranging from $\mathrm{T}_{40} / \mathrm{T}_{42}$ to $\mathrm{T}_{54}$ that are characteristic of ruminant or dairy fats (Dudd et al. 1999; Mukherjee et al. 2007). The distribution with low quantities of $\mathrm{T}_{42}, \mathrm{~T}_{44}$ and $\mathrm{T}_{46}$ are attributed to ruminant adipose fats. It should be mentioned, however, that TAGs are likely to be preferentially degraded. Degradation pathways are not fully understood and might differ depending on the use and burial environment. Therefore, TAG distribution has to be considered as preliminary information to assess the origin of fats.
The identification of TAGs in our samples was first performed with HT GC-MS. MAGs, DAGs and TAGs were detected in 12 samples, together with relatively high amounts of $\mathrm{C}_{16: 0}$ and $\mathrm{C}_{18: 0}$ fatty acids. A relatively broad TAG distribution in the range from $\mathrm{T}_{44}$ to $\mathrm{T}_{54}$, maximising at $\mathrm{T}_{50}$ or $\mathrm{T}_{54}$, was observed in five samples (159MT, 79MT, MaTr130, MaTr174, MaTr602 ) indicating the presence of ruminant adipose or dairy fats. Two samples (MaTr115, MaTr174) presented a narrower distribution, from $\mathrm{T}_{50}$ to $\mathrm{T}_{54}$, indicating the presence of ruminant adipose fats.

The identification of original products was further examined by ESI Q-TOF MS and ESI-MS/MS methods to obtain more information about the structure of TAGs. This method enables the TAGs identification down to $\mathrm{T}_{28}$ and could be used to detect dairy fats (Garnier et al. 2007; Mirabaud et al. 2007; Regert 2011) since the HT GC could not detect TAGs under $\mathrm{T}_{40}$. The distribution of TAGs obtained by ESI Q-TOF MS was possible only for three samples (MaTr115, MaTr130, 79MT). The TAGs distribution in MaTr115 was closer to that observed by HT GC: $\mathrm{T}_{42}-\mathrm{T}_{52}$ instead of $\mathrm{T}_{50}-\mathrm{T}_{54}\left(\mathrm{~T}_{54}\right.$ was not detected by ESI Q-TOF MS probably due to its poor ionisation yield).

In the other two samples, 79MT and MaTr130, a large TAG distribution from $\mathrm{T}_{28}$ to $\mathrm{T}_{52}$ was observed, 
which indicates the presence of dairy fat products (Fig. 6). The comparison of these TAG and DAG distributions with data on goat versus cow milk favours goat milk (Mirabaud et al. 2007). A more precise differentiation between cow and goat milk could be obtained from fatty acid distribution in $\mathrm{T}_{44: 0}$ using ESI-MS/ MS fragmentation, but this was not possible due to the low quantity and poor ionisation yield of $\mathrm{T}_{44: 0}$ in our sample; thus a more precise discrimination of the specific origin of dairy fat could not be performed.

The stable carbon isotope composition of individual fatty acids is a complementary tool in determining the origin of residues in ancient pottery vessels. In Figure 7, we present the $\delta^{13} \mathrm{C}$ values of modern reference animal fats of both Neolithic domesticates and the animals that are actually bred in the region, as well as the values from the Mala Triglavca pottery samples. The $\delta{ }^{13} \mathrm{C}_{16: 0}$ and $\delta 13 \mathrm{C}_{18: 0}$ values in different reference animal fats ranged from -37.5 to $-27.2 \%$ o (Tab. 2). The modern reference animals (cow, sheep and goat) were fed exclusively on C3 local forage grasses. The theoretical mixing curves were determined from the modern reference animal fats, as in Simon E. Woodbury et al. (1995), to illustrate the $\delta^{13} \mathrm{C}$ values which would result from mixing sheep and porcine fats in the vessels. Each dot in Figure 7 indicates the effect of mixing a specific percentage of each of the respective commodities and their influence on the $\delta 13 \mathrm{C}_{16: 0}$ and $\delta 13 \mathrm{C}_{18: 0}$ values. It should be further mentioned that modern dairy ruminant fats (milk, butter and cheese; see Tab. 3) have higher $\delta^{13} \mathrm{C}_{16: 0}$ and $\delta^{13} \mathrm{C}_{18: 0}$ values compared to adipose fats, which can be explained by the distinct metabolic pathway of milk fatty acids. The $\mathrm{C}_{16: 0}$ fatty acid is the major fatty acid produced from fermenting dietary sugars, while the $\mathrm{C}_{18: 0}$ fatty acid derives mainly from dietary plant fatty acids. These different sources explain why the values are up to $7.9 \%$ o lower $\delta^{13} \mathrm{C}_{18: 0}$ compared to $\delta^{13} \mathrm{C}_{16: 0}$. In addition, the $\delta^{13} \mathrm{C}_{16: 0}$ and $\delta 13 \mathrm{C}_{18: 0}$ values in sheep cheese and curd are enriched in ${ }^{13} \mathrm{C}$ relative to the raw milk samples. This enrichment is probably the consequence of the bacterial degradation of long-chain fatty acids during cheese or curd production and storage. These data are in good agreement with the published data on reference modern animal fats (Spangenberg et al. 2006; Richter et al. 2012a; 2012b).

Since the data points plot between the reference animal fat fields presented in Figure 7, extensive mixing of animal products could be identified. The $\delta{ }^{13} \mathrm{C}_{16: 0}$ and $\delta 13 \mathrm{C}_{18: 0}$ values from four samples (MaTr130, MaTr137, MaTr602, 161MT) plot within the area of the mixture between adipose and dairy fats, while another seven samples (MaTr145, MaTr147, MaTr159, MaTr173, MaTr600, 79MT, 87MT) plot within the reference ruminant adipose fat. Further four samples (MaTr100, MaTr112, MaTr151, 159MT) plot in the area between porcine and ruminant adipose fat, and the remaining seven samples (MaTr53, MaTr107, MaTr115, MaTr116, MaTr470, MaTr599, MaTr606) do not plot along any of the theoretical mixing curves, thus suggesting an admixture of fats of different origins and different degrees of degradation. Only one sherd plots in the area of dairy fat (MaTr174).

A more precise differentiation between non-ruminant adipose, ruminant adipose and ruminant dairy fats can be obtained in the diagram, where $\Delta^{13} \mathrm{C}$ values $\left(\delta^{13} \mathrm{C}_{18: 0}-\delta^{13} \mathrm{C}_{16: 0}\right)$ are plotted against the $\delta^{13} \mathrm{C}_{16: 0}$ values (Fig. 8 ). $\Delta^{13 \mathrm{C}}$ values of lower than $-3.3 \%$ are used as a criterion for determining dairy foods (Evershed et al. 2002; 2008; Copley et al. 2003; 2005; Mukherjee et al. 2007; Dunne et al. 2012). Four ves-

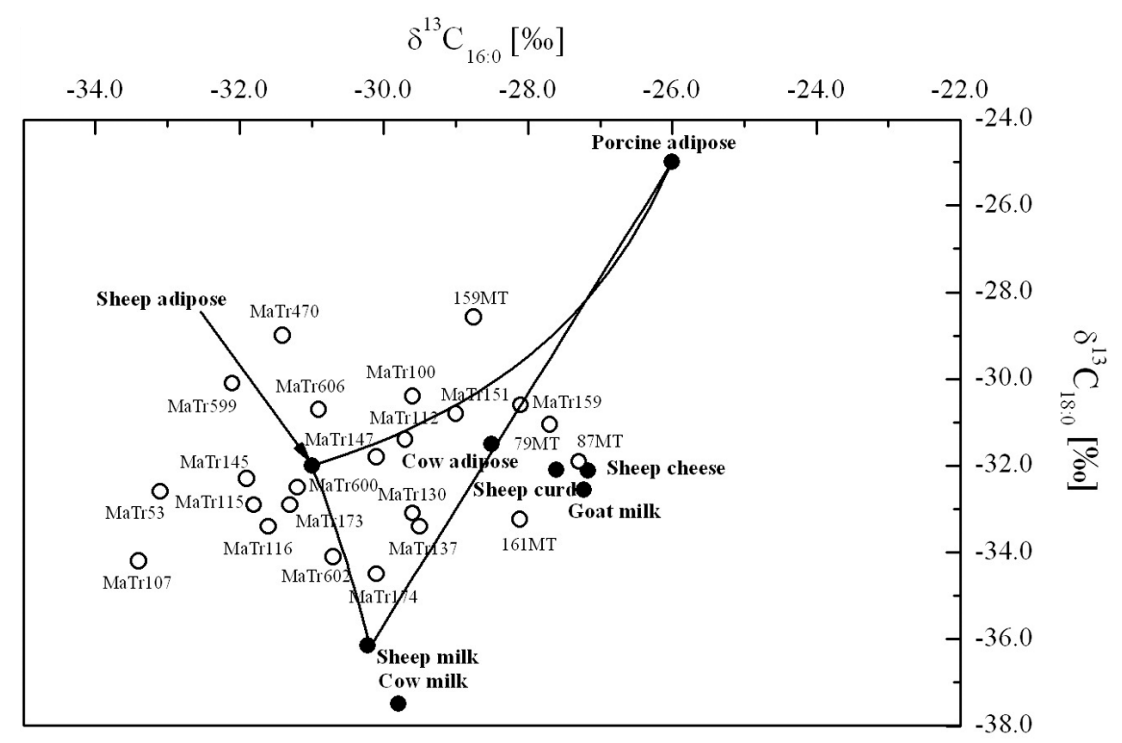

Fig. 7. Plot of the $\delta^{13} \mathrm{C}$ of $C_{18: 0}$ and $C_{16: 0}$ fatty acids of modern reference fats and the lipid extracts of potsherds from Mala Triglavca (see Tabs. 2 and 3). Open circles represent the archaeological fats. The theoretical mixing curve was determined as in Woodbury et al. (1995) to illustrate $\delta^{13} \mathrm{C}$ values resulting from the mixing of these fats. 
sels from Mala Triglavca (MaTr174, MaTr137, 161MT, 87MT) are plotted in this region, while another three (MaTr130, MaTr602, 79MT) are plotted on the border of two ranges, thus suggesting mixing of different types of fats during pottery use. In total, $30 \%$ of the pottery samples contained lipids characteristic of dairy fats, indicating that the processing of dairy products in vessels was quite extensive during the Neolithic period at Mala Triglavca.

As presented in Figure 8, 43\% of pottery samples plot in the range for ruminant adipose fats. The $\mathrm{C}_{16: 0} / \mathrm{C}_{18: 0}$ ratios of fatty acids for these samples range between 1.3 and 2.0 (Tab. 2), which is typical for ruminant adipose fat (Copley et al. 2005). The $\delta^{15 \mathrm{~N}}$ values suggest that people at Mala Triglavca used diverse domesticated animal products (from cattle, sheep and goats) in their diet. A further $17 \%$ of the samples (MaTr53, MaTr145, MaTr606, 159MT) fall close to the limit value between non-ruminant and ruminant meat $(\Delta 13 \mathrm{C}=0 \%)$. However, the later samples may not be assigned exclusively to meat mixtures, but also to a mixture of plant and animal fats. Two of the samples (MaTr470, MaTr599) plot in the area of non-ruminant fats, and their high $\delta 15 \mathrm{~N}$ values of +8.4 and $10.3 \%$ o (Tab. 2) suggest the presence of fresh-water organisms such as molluscs and fish fats. No evidence of porcine fat was found in the pottery when observing the $\delta^{13} \mathrm{C}$ values of $\mathrm{C}_{16: 0}$ and $\mathrm{C}_{18: 0}$ fatty acids.

\section{Processing of plant and beeswax products}

The evidence of plant lipids in pottery vessels can be detected by a homologous series of long chain $n$-alkanes $\mathrm{C}_{16}-\mathrm{C}_{33}$ (odd-over-even carbon number predominance), $n$-alcohols, $\beta$-sitosterols and palmitic and stearic wax esters $\left(\mathrm{C}_{40}-\mathrm{C}_{52}\right)$ (Bianchi 1995). Some or all of these compounds were also detected in 14 pottery samples, although always in low amounts. Six samples (MaTr53, MaTr107, MaTr145, MaTr470, MaTr599, MaTr606), were associated with non-ruminant or mixed adipose fats, five samples (MaTr112, MaTr115, MaTr145, MaTr151, MaTr159) were associated with ruminant adipose fats and three samples
(79MT, 87MT, MaTr602) with dairy fats, suggesting that the pots were used for mixed food processing and storage. Sample MaTr606 was used mainly for preparing or storing plant foods, which can be proven by the highest abundance of $\mathrm{C}_{16: 0}$, high $\mathrm{C}_{16: 0} / \mathrm{C}_{18: 0}$ ratio of 3.6 and the lowest $\delta 15 \mathrm{~N}$ value of $+0.1 \%$. Overall, $48 \%$ of the pottery vessels contained plant lipid components, indicating the importance of plants in the Mala Triglavca population diet.

The presence of wax esters, characteristic of beeswax, may indicate the addition of honey to other food or the application of beeswax to pottery vessels to improve their impermeability (Regert et al. 2001; Evershed et al. 2003; Copley et al. 2005). Six pottery samples contained beeswax-derived lipids; two of them also yielded evidence of fresh-water fish (MaTr470, MaTr599) and a further four samples contained animal fats and beeswax (MaTr107, MaTr145, MaTr53, MaTr159). Although the quantity is relatively low (21\% of all of the samples), it indicates that this particular commodity was utilised in the Mala Triglavca vessels associated with cooking/processing food, or applied as a coating, which made them waterproof and more resistant.

\section{Different use of vessels}

The results obtained from lipid analyses indicate markedly different uses of the Mala Triglavca pottery. It was found that $30 \%$ of sampled pottery con- 
tain lipids characteristic of dairy fats (MaTr174, MaTr137, 161MT, 87MT, MaTr130, MaTr602, 79MT), indicating that the processing of dairy products in pottery vessels was quite extensive. The TAG distributions in samples MaTr130 and 79MT showed the residues of dairy products that probably derived from goat milk. We have found evidence that five vessels were used to process only animal fats either of ruminant origin (MaTr116, MaTr173, MaTr600) or a mixture of ruminant and non-ruminant origin (MaTr53, MaTr100). However, none of the total lipid extracts contained porcine adipose fat. The appearance of both animal and plant biomarkers observed in 14 pottery samples (see Tab. 2) suggests mixed food processing and storage. Only one of them (MaTr606) was mainly used in preparing or storing plant foods. Moreover, our results show that some vessels were also used to process aquatic organisms such as molluscs and fish (MaTr470, MaTr599). The presence of beeswax in some of the vessels suggests the storage and use of honey or, more probably, the use of beeswax for waterproofing.

The lipid analysis of Neolithic vessels from Mala Triglavca showed a variety of different foods prepared and consumed at the site (Tab. 2). If we look closely at the most common vessels type at the site, i.e. the Vlaška bowl, we can observe that lipids of ruminant adipose and dairy fats are the most common residue, but freshwater fish, plants and a mixture of different fats were also detected in the bowls. Therefore, we may conclude that these bowls had no specific function, but were rather treated as universal vessels for preparing and consuming a variety of different foods. Typical Vlaška bowls also contained lipids derived from beeswax, which can indicate the technique of applying beeswax to waterproof vessels, but can also suggest the use of honey in food preparation. Other types of vessel showed the use of ruminant adipose and dairy fats in dishes (MaTr107, MaTr174) and ruminant fats in one pot from Mala Triglavca (MaTr173).
The remains of dairy lipids were detected in 29\% of the samples, most of them Vlaška bowls (MaTr130, MaTr137, MaTr602, 79MT, 161MT), but also in a beaker (87MT; Mlekuž et al. 2008.247) and a dish (MaTr174), well embedded in the time span 54675227 calBC. Sample MaTr130 with an incised plant motif and sample 161MT with incised pendant triangles (Fig. 5.3-4) (Mlekuž et al. 2008. Fig. 6; Šoberl et al. 2008.Tab. 1) are two of the most prominent Vlaška vessels with preserved dairy fats from the site.

\section{Conclusions}

The Mala Triglavca case study shows that the Early Neolithic economy in Caput Adriae was mixed. It consisted of both milk and processed milk (low-lactose food), meat (ruminants and non-ruminants) animal products, and fresh-water fish and various plants. The Vlaška group herders managed a broader spectrum of resources than ovicaprids alone, and by fermenting milk they were able to produce a wide range of low-lactose, storable products.

Archaeological and biochemical data suggest that dairying was adopted in the Early Neolithic in Europe. Archaeogenetic data show, on the contrary, the absence of the allelic variant $-13910^{*} \mathrm{~T}$ in Neolithic populations in Europe, and that their lactase persistence was very low and may have even been zero. Thus pastoralism appeared before lactase persistence arose or became frequent. We may assume, therefore, that under normal circumstances lactase persistence is not necessarily under very strong selection in these populations and fits with the hypothesis that dairying, milk consumption and fermented milk consumption emerged before the genetic adaptation.

\section{ACKNOWLEDGEMENTS}

The research was supported by the Slovenian Research Agency: Project J6-4085. 


\section{References}

Aoki K. 1986. A stochastic model of gene-culture coevolution suggested by the culture-historical hypothesis. Proceedings of the National Academy of Sciences of the United States of America 83: 2929-2933.

2001. Theorethical and empirical aspects of gene-culture coevolution. Theoretical Population Biology 59 (4): 253-261.

Barfield L. 1972. The first Neolithic cultures of Northeastern Italy. Fundamenta A/3, Teil 7: 182-216.

1999. The Moser collection in the Naturhistorisches $\mathrm{Mu}-$ seum, Vienna. Atti della Società per la Preistoria e Protostoria della Regione Friuli-Venezia Giulia 11: 19-62.

Beja-Pereira A. 2006. The origin of European cattle: Evidence from modern and ancient DNA. Proceedings of the National Academy of Science 103(21): 8113-8118.

Beja-Pereira A., Alexandrino P., Bessa I., Carretero Y., Dunner S., Ferrand N., Jordana J., Laloe D., Moazami-Goudarzi K., Sanchez A. and Cañon J. 2003. Genetic Characterization of Southwestern European Bovine Breeds: A Historical and Biogeographical Reassessment With a Set of 16 Microsatellites. Journal of Heredity 94(3): 243-250.

Berger J.-F., Guilaine J. 2009. The 8200calBP abrupt environmental change and the Neolithic transition: A Mediterranean perspective. Quaternary International 200: 3149.

Biagi P. 2003. A review of the late Mesolithic in Italy and its implications for the Neolithic transition. In A. J. Ammerman, P. Biagi (eds.), The widening harvest: the Neolithic transition in Europe: looking back, looking forward. Archaeological Institute of America. Boston: 133-155.

Biagi P., Spataro M. 2001. Plotting the evidence: some aspects of the radiocarbon chronology of the MesolithicNeolithic transition in the Mediterranean basin. Atti della Societa per la Preistoria della Regione Friuli VeneziaGiulia XII: 15-54.

Biagi P., Starnini E. and Voytek B. 2008. The MesolithicNeolithic transition in the Trieste Karst (north-eastern Italy) as seen from the excavations at the Edera Cave. In C. Bonsall, V. Boroneanţ and I. Radovanović (eds.), The Iron Gates in prehistory: new perspectives. BAR IS 189. Archaeopress. Oxford: 3250-3260.

Bianchi G. 1995. Plant waxes. In R. J. Hamilton (ed.), Waxes: Chemistry, Molecular Biology and Functions. The Oily Press, Dundee: 175-222.
Bloom G., Sherman P. W. 2005. Dairying barriers affect the distribution of lactose malabsorption. Evolution and Human Behavior 26(4): 301-312.

Bonsall C., Mlekuž D., Bartosiewicz L. and Pickard C. 2013. Early Farming Adaptations of the Northeast Adriatic Karst. In S. Colledge, J. Conolly, K. Dobney, K. Manning and S. Shennan (eds.), Domestic Animals in Southwest Asia and Europe. Left Coast Press. Walnut Creek, CA: 145-160.

Brami M., Heyd V. 2011. The origins of Europe's first farmers: The role of Hacilar and Western Anatolia, fifty years on. Praehistorische Zeitschrift 86(2): 165-206.

Burger J., Thomas M. G. 2011. The Palaeopopulationgenetics of Humans, Cattle and Dairying in Neolithic Europe. In R. Pinhasi, J. T. Stock (eds.), Human Bioarchaeology of the Transition to Agriculture. John Wiley \& Sons, Ltd. Chichester: 371-384.

Çakırlar C. 2012a. Neolithic Dairy Technology at the European-Anatolian Frontier: Implications of Archaeozoological Evidence from Ulucak Höyük, Izmir, Turkey, ca. 7000-5700 cal. BC. Anthropozoologica 47(2): 77-98.

Çakırlar C. 2012b. The evolution of animal husbandry in Neolithic centralwest Anatolia: the zooarchaeological record from Ulucak Höyük (c. 7040-5660 cal. BC, Izmir, Turkey). Anatolian Studies 62: 1-33.

Christie W. W. 1981. The effect on diet and other factors on the lipid composition of ruminant tissues and milk. In W. W. Christie (ed.), Lipid metabolism in ruminant animals. Pergamon. Oxford: 193-226.

Copley M. S., Berstan R., Dudd S. N., Straker V., Payne S. and Evershed R. P. 2005. Dairy in antiquity, I: evidence from absorbed lipid residues dating to British Iron Age. Journal of Archaeological Science 32: 485-503.

Copley M. S., Berstan R., Dudd S. N., Dovherty G., Mukherjee A. J., Straker V., Payne S. and Evershed R. P. 2003. Direct chemical evidence for widespread dairying in prehistoric Britain. Proceedings of the National Academy of Science 100: 1524-1529.

Craig O. E., Chapman J., Heron C., Willis L. H., Bartosiewicz L., Taylor G., Whittle A. and M. Collins. 2005. Did the first farmers of central and eastern Europe produce dairy foods? Antiquity 79(306): 882-894.

Craig 0. E., Forster M., Andersen S. H., Koch E., Crombé P., Milner N. J., Stern B., Bailey G. N. and Heron C. P. 2007. Molecular and isotopic demonstration of the processing of aquatic products in Northern European prehistoric pottery. Archaeometry 49: 135-152. 
Dudd S. N., Evershed R. P. and Gibson A. M. 1999. Evidence for varying patterns of exploitation of animal products in different prehistoric pottery traditions based on lipids preserved in surface and absorbed residues. Journal of Archaeological Science 26: 1473-1482.

Dahl G., Hjort A. 1976. Having herds: pastoral herd growth and household economy. University of Stockholm. Stockholm.

Dunne J., Evershed R. P., Salque M., Cramp L., Bruni S., Ryan K., Biagetti S. and Di Lernia S. 2012. First dairying in green Saharan Africa in the fifth millennium BC. Nature 486: 390-394.

Edwards J. C. and 11 authors. 2011. Dual Origins of Dairy Cattle Farming - Evidence from a Comprehensive Survey of European Y-Chromosomal Variation. PLoS One 6(1): e15922.

Enattah N. S., Sahi T., Savilahti E., Terwilliger J. D., Peltonen L. and Järvelä I. 2002. Identification of a variant associated with adult-type Hypolactasia. Nature Genetics 30: $233-237$.

Enattah N. S. and 26 authors. 2007. Evidence of Still-Ongoing Convergence Evolution of the Lactase Persistence T-13910 Alleles in Humans. The American Journal of Human Genetics 81: 615-625.

Enattah N. S. and 21 authors. 2008. Independent Introduction of Two Lactase-Persistence Alleles into Human Populations Reflects Different History of Adaptation to Milk Culture. The American Journal of Human Genetics 82: 57-72.

Evershed R. P., Heron C. and Goad L. J. 1990. Analysis of Organic Residues of Archaeological Origin by High-Temperature Gas Chromatography/Mass Spectrometry. Analyst 115: 1339-1342.

Evershed R. P., Arnot K. I., Eglinton G. and Charters S. 1994. Application of isotope ratio monitoring gas chromatography-mass spectrometry to the analysis of organic residues of archaeological origin. Analyst 119: 909- 914.

Evershed R. P., Dudd S. N., Copley M. S., Berstan R., Stott A. W., Mottram H., Buckley S. A. and Crossman Z. 2002. Chemistry of archaeological animal fats. Accounts of Chemical Research 35(8): 660-668.

Evershed R. P. and 21 authors. 2008. Earliest date for milk use in the Near East and southeastern Europe linked to cattle herding. Nature 455: 528-531.

Forenbaher S., Miracle P. T. 2005. The spread of farming in the eastern Adriatic. Antiquity 79(305): 514-528.
2006. Pupićina Cave and the spread of farming in the Eastern Adriatic. In P. T. Miracle, S. Forenbaher (eds.), Prehistoric herders of northern Istria: the archaeology of Pupićina Cave. Vol. 1. Arheološki Muzej Istre. Pula: 483-523.

Forenbaher S., Kaiser T. 2006. The pottery of Pupićina Cave. In P. T. Miracle, S. Forenbaher (eds.), Prehistoric herders of northern Istria: the archaeology of Pupicina Cave. Vol. 1. Arheološki Muzej Istre. Pula: 163-223.

Forenbaher S., Kaiser T. and Miracle P. T. 2013. Dating the East Adriatic Neolithic. European Journal of Archaeology 16(4): 589-609.

Garnier N., Rolando C., Munk Høtje J. and Tokarski C. 2007. Analysis of archaeological triacylglycerols by high resolution nanoESI, FT-ICR MS and IRMPD MS/MS: application to $5^{\text {th }}$ century $\mathrm{BC}-4^{\text {th }}$ century $\mathrm{AD}$ oil lamps from 01 bia (Ukraine). International Journal of Mass Spectrometry 284: 47-56.

Gerbault P. 2012. Milking the data. Modelling the coevolution of lactase persistence and dairying in Europe. In F. Feulner, P. Gerbault, R. Gillis, H. Hollund, R. Howcroft, M. Leonardi, A. Liebert, M. Raghavan, M. Salque, 0. Sverrisdóttir, M. Teasdale, N. van Doorn and C. Wright (eds.), May Contain Traces of Milk. Investigating the role of dairy farming and milk consumption in the European Neolithic. Lactose Persistence and Early Cultural History of Europe. LeCHE. The University of York. Heslington: 191-210.

Gerbault P., Moret C., Currat M. and Sanchez-Mazas A. 2009. Impact of Selection and Demography on the Diffusion of Lactase Persistence. PLoS One 4(7): e6369.

Gerbault P., Liebert A., Itan Y., Powell A., Currat M., Burger J., Swallow D. M. and Thomas M. G. 2011. Evolution of lactase persistence: an example of human niche construction. Philolosphical Transactions of Royal Society B 366: 863-877.

Gilli E., Montagnari Kokelj E. 1992 (1993). Grotta dei Ciclami nel Carso Triestino. Atti della Società per la Preistoria e Protostoria della Regione Friuli-Venezia Giulia 7: $62-162$.

1996. La Grotta degli Zingari nel Carso Triestino (Materiali degli scavi 1961-1965). Atti della Società per la Preistoria e Protostoria della Regione Friuli-Venezia Giulia 9: 63-126.

Gregg M. W., Slater G. F. 2010. A new method for extraction, isolation and transesterification of free fatty acids from archaeological pottery. Archaeometry 52: 833-854. 
Halstead P. 1996. Pastoralism or household herding? Problems of scale and specialization in early Grek animal husbandry. World Archaeology 28(18): 20-42.

Helmer D., Gourichon L. and Vila E. 2007. The development of the exploitation of products from Capra and Ovis (meat, milk and fleece) from the PPNB to the Early Bronze in the northern Near East (8700 to $2000 \mathrm{BC}$ cal.). Anthropozoologica 42(2): 41-69.

Holden C., Mace R. 1997. Phylogenetic Analysis of the Evolution of Lactose Digestionin Adults. Human Biology 69 (5): $605-628$.

Ingold T. 1980. Hunters, pastoralists and ranchers. Cambridge University Press. Cambridge.

Ingram C. J. E., Elamin M. F., Mulcare C. A., Weale M. E., Tarekegn A., Oljira Raga T., Bekele E., Elamin F. M., Thomas M. G. Bradman N. and Swallow D. M. 2007. A novel polymorphism associated with lactose tolerance in Africa: multiple causes for lactase persistence? Human Genetics 120: $779-788$.

Ingram C. J. E., Mulcare C. A., Itan Y., Thomas M. G. and Swallow D. M. 2009. Lactose digestion and the evolutionary genetics of lactase persistence. Human Genetics 124: 579-591.

Itan Y., Powell A., Beaumont M. A., Burger J., Thomas M. G. 2009. The Origins of Lactase Persistence in Europe. PLoS Computational Biology 5(8): e1000491.

Itan Y., Jones B. L., Ingram C. J., Swallow D. M. and Thomas M. G. 2010. A worldwide correlation of lactase persistence phenotype and genotypes. BMC Evolutionary Biology 10: 36. doi: 10.1186/1471-2148-10-36.

Kimpe K., Jacobs P. A. and Waelkens M. 2002. Mass spectrometric methods prove the use of beeswax and ruminant fats in late Roman cooking pots. Journal of Chromatography A 968: 151-160.

Lacan M., Keyser C., Ricaut F.X. , Brucato N., Duranthon F., Guilaine J., Crubézy E., and Ludes B. 2011. Ancient DNA reveals male diffusion through the Neolithic Mediterranean route. Proceedings of the National Academy of Sciences of the United States of America 108(24): 97889791.

Leonardi M., Gerbault P., Thomas M. G. and Burger J. 2012. The evolution of lactase persistence in Europe. A synthesis of archaeological and genetic evidence. International Dairy Journal 22: 88-97.

Liebert A. 2012. The Milkybars are on me. Lactase persistence and its traces with DNA. In F. Feulner, P. Gerbault,
R. Gillis, H. Hollund, R. Howcroft, M. Leonardi, A. Liebert, M. Raghavan, M. Salque, O. Sverrisdóttir, M. Teasdale, N. van Doorn and C. Wright (eds.), May Contain Traces of Milk. Investigating the role of dairy farming and milk consumption in the European Neolithic. Lactose Persistence and Early Cultural History of Europe. LeCHE. The University of York. Heslington: 75-88

Linderholm A. 2011. The Genetics of the Neolithic Transition: New Light on Differences Between Hunter-Gatherers and Farmers in Southern Sweden. In R. Pinhasi, J. T. Stock (eds.), Human Bioarchaeology of the Transition to Agriculture. John Wiley \& Sons. Chichester: 385-402.

Mirabaud S., Rolando C. and Regert M. 2007. Molecular criteria for discriminating adipose fats and milk from different species by nano-ESI MS and MS/MS of their triacylglycerols: application to archaeological remains. Analytical Chemistry 79: 6182-6192.

Miracle P., Forenbaher S. 2005. Neolithic and Bronze-Age Herders of Pupičina Cave, Croatia. Journal of Field Archaeology 30: 255-81.

Miracle P. T., Pugsley L. 2006. Vertebrate faunal remains from Pupićina Cave. In P. T. Miracle, S. Forenbaher (eds.), Prehistoric herders of northern Istria: the archaeology of Pupicina Cave. Vol. 1. Arheološki Muzej Istre. Pula: 259-399.

Mlekuž D. 2005. The ethnography of the Cyclops: Neolithic pastoralists in the eastern Adriatic. Documenta Praehistorica 32: 15-51.

2006. Meat or milk? : Neolithic economies of Caput Adriae. In A. Pessina, P. Visentini (eds.), Preistoria dell' Italia settentrionale: studi in ricordo di Bernardino Bagolin: atti del convegno. Pubblicazioni varie del Museo friulano di storia naturale 53. Comune: Museo friulano di storia naturale. Udine: 453-458.

Mlekuž D., Budja M., Payton R., Bonsall C. and Žibrat Gašparič A. 2008. Reassessing the Mesolithic/Neolithic 'gap' in Southeast European cave sequences. Documenta Praehistorica 35: 237-251.

Mottram H. R., Dudd S. N., Lawrence G. J., Stott A. W. and Evershed R. P. 1999. New chromatographic, mass spectrometric and stable isotope approaches to the classification of degraded animal fats preserved in archaeological pottery. Journal of Chromatography A 833: 209-21.

Mukherjee A. J., Berstan R., Copley M. S., Gibson A. M. and Evershed R. P. 2007. Compound-specific stable carbon isotopic detection of pig product processing in British late Neolithic pottery. Antiquity 81(313): 743-754. 
Müller J. 1994. Das Ostadriatische Frühneolithikum. Die Impresso-Kultur und die Neolithisierung des Adriaraumes. Prähistorische Archäologie in Südosteuropa 9. Wissenschaftsverlag Volker Spiess. Berlin.

Nagy D., Tömöry G., Csányi B., Bogácsi-Szabó E., Czibula A., Priskin K., Bede O., Bartosiewicz L., Stephen Downes C. and Raskó I. 2011. Comparison of Lactase Persistence Polymorphism in Ancient and Present-Day Hungarian Populations. American Journal of Physical Anthropology 145: 262-269.

Ogrinc N., Budja M. 2005. Paleodietary reconstruction of a Neolithic population in Slovenia: A stable isotope approach. Chemical Geology 218: 103-116.

Ogrinc N., Gams Petrišič M., Žigon D., Žibrat Gašparič A. and Budja M. 2012. Pots and lipids: molecular and isotope evidence of food processing at Maharski prekop. Documenta Praehistorica 39: 339-347.

Özdoğan M. 2011. Archaeological evidence on the westward expansion of farming communities from eastern Anatolia to the Aegean and the Balkans'. Current Anthropology 52(S4): 415-430.

Panesar P. S. 2011. Fermented Dairy Products: Starter Cultures and Potential Nutritional Benefits. Food and Nutrition Sciences 2: 47-51.

Payne S. 1973. Kill-off patterns in sheep and goats: the mandibles from Asvan Kale. Anatolian Studies 23: 281303.

Pinhasi R., Fort J. and Ammerman A. J. 2005. Tracing the Origin and Spread of Agriculture in Europe. PLoS Biology 3(12): 2220-2228.

Plantinga T. S., Alonso S., Izagirre N., Hervella M., Fregel R., van der Meer J. W. M., Netea M. G. and de la Rúa C. 2012. Low prevalence of lactase persistence in Neolithic South-West Europe. European Journal of Human Genetics 20: 778-782.

Polet C., Katzenberg M. A. 2003. Reconstruction of the diet in the mediaeval monastic community from the coast of Belgium. Journal of Archaeological Science 30: 525533.

Privat K. L., O'Connell T. and Richards M. P. 2002. Stable isotope analysis of human and faunal remains from the Anglo-Saxon cemetery at Berinsfield, Oxfordshire: Dietary and social implication. Journal of Archaeological Science 29: $779-790$.

Regert M., Colinart S., Degrand L. and Decavallas 0. 2001. Chemical alteration and use of beeswax through time: ac- celerated ageing test and analysis of archaeological samples from various environmental contexts. Archaeometry 43(4): 549-569.

Regert M. 2011. Analytical strategies for discriminating archeological fatty substances from animal origin. Mass Spectrometry Reviews 30: 177-220.

Richards M. P., Pearson J. A., Molleson T. I., Russell N. and Martin L. 2003. Stable isotope evidence of diet at Neolithic Çatalhöyük, Turkey. Journal of Archaeological Science 30: 67-76.

Richter E. K., Spangenber J. E., Willems H., Kreuzer M. and Leiber F. 2012a. Stable carbon isotope composition of perirenal adipose tissue fatty acids from Engadine sheep grazing either mountain or lowland pasture. Journal of Animal Science 90: 905-913.

Richter E. K., Spangenberg J. E., Klevenhusen F., Soliva C. R., Kreuzer M. and Leiber F. 2012b. Stable carbon isotope composition of $\mathrm{c} 9$, t11-conjugated linoleic acid in cow's milk as related to dietary fatty acids. Lipids 47: 161-169.

Rowley-Conwy P. 2000. Milking caprines, hunting pigs: the Neolithic economy of Arene Candide in its West Mediterranean context. In P. Rowley-Conwy (ed.), Animal bones, human societies. 0xbow Books. Oxford: 124-132.

Rowley-Conwy P., Layton R. 2011. Foraging and farming as niche construction: stable and unstable adaptations. Philolosphical Transactions of Royal Society B 366: 849-862.

Rowley-Conwy P., Gourichon L., Helmer D. and Vigne J.D. 2013. Early domestic animals in Italy, Istria, the Tyrrhenian Islands and Southern France. In S. Colledge, J. Conolly, K. Dobney, K. Manning and S. Shennan (eds.), Domestic Animals in Southwest Asia and Europe. Left Coast Press. Walnut Creek, CA: 161-194.

Salque M., Bogucki P. I., Pyzel J., Sobkowiak-Tabaka I., Grygiel R., Szmyt M. and Evershed R. P. 2013. Earliest evidence for cheese making in the sixth millennium $\mathrm{BC}$ in northern Europe. Nature 493(7433): 522-525.

Spangenberg J. E., Jacomet S. and Schibler J. 2006. Chemical analyses of organic residues in archaeological pottery from Arbon Bleiche 3, Switzerland - evidence for dairying in the late Neolithic. Journal of Archaeological Science 33: 1-13.

Šoberl L., Žibrat Gašparič A., Budja M. and Evershed R. P. 2008. Early herding practices revealed through organic residue analysis of pottery from the early Neolithic rock shelter of Mala Triglavca, Slovenia. Documenta Praehistorica 35: 253-260. 
Tishkoff S. A. and 18 authors. 2007. Convergent adaptation of human lactase persistence in Africa and Europe. Nature Genetics 39: 31-40.

Thissen L. Özbal H., Türkekul Bıyık A., Gerritsen F. and Özbal R. 2010. The land of milk? Approaching dietary preferences of Late Neolithic communities in NW Anatolia. Leiden Journal of Pottery Studies 26: 157-172.

Vigne J.-D. 2008. Zooarchaeological Aspects of the Neolithic Diet Transition in the Near East and Europe, and Their Putative Relationships with the Neolithic Demographic Transition. In J.-P. Bocquet-Appel, O. Bar-Yosef (eds.), The Neolithic Demographic Transition and its Consequences. Springer. New York: 179-205.

2011. The origins of animal domestication and husbandry: A major change in the history of humanity and the biosphere. Comptes rendus Biologies 334(3): 171-181.

Vigne J.-D., Helmer D. 2007. Was milk a "secondary product" in the Old World Neolithisation process? Its role in the domestication of cattle, sheep and goats. Anthropozoologica 42(2): 9-40.

Woodbury S. E., Evershed R. P., Rosell J. B., Griffiths R. E. and Farnell P. 1995. Detection of vegetable oil adulteration using gas chromatography combustion/isotope ratio mass spectrometry. Analytical Chemistry 67: 26852690.

Žibrat Gašparič A. 2004. Archaeometrical analysis of Neolithic pottery from the Divača region, Slovenia. Documenta Praehistorica 31: 205-220. 